Florida International University FIU Digital Commons

\title{
The distribution and abundance of the exotic and native urban avifauna in Miami-Dade County Florida
}

Omar Zaid Abdelrahman

Florida International University

DOI: $10.25148 /$ etd.FI13101504

Follow this and additional works at: https://digitalcommons.fiu.edu/etd

Part of the Biology Commons

\section{Recommended Citation}

Abdelrahman, Omar Zaid, "The distribution and abundance of the exotic and native urban avifauna in Miami-Dade County Florida" (2000). FIU Electronic Theses and Dissertations. 1062.

https://digitalcommons.fiu.edu/etd/1062 
FLORIDA INTERNATIONAL UNIVERSITY

Miami, Florida

THE DISTRIBUTION AND ABUNDANCE OF THE EXOTIC AND NATIVE URBAN AVIFAUNA IN MIAMI-DADE COUNTY FLORIDA

A thesis submitted in partial fulfillment of the requirements for the degree of

MASTER OF SCIENCE

in

BIOLOGY

by

Omar Zaid Abdelrahman 
To: Dean Arthur W. Herriott

College of Arts and Sciences

This thesis, written by Omar Zaid Abdelrahman and entitled The Distribution and Abundance of the Exotic and Native Urban Avifauna in Miami-Dade County Florida, having been approved in respect to style and intellectual content, is referred to you for judgment.

We have read this thesis and recommend that it be approved.

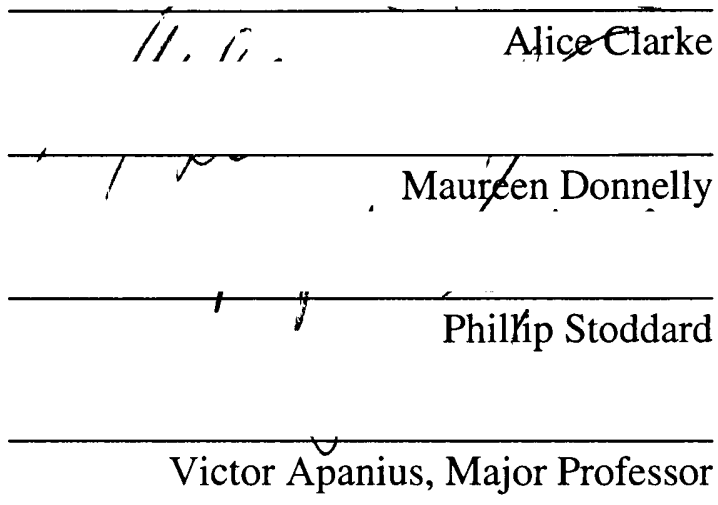

Date of Defense: March 14, 2000

The thesis of Omar Zaid Abdelrahman is approved.

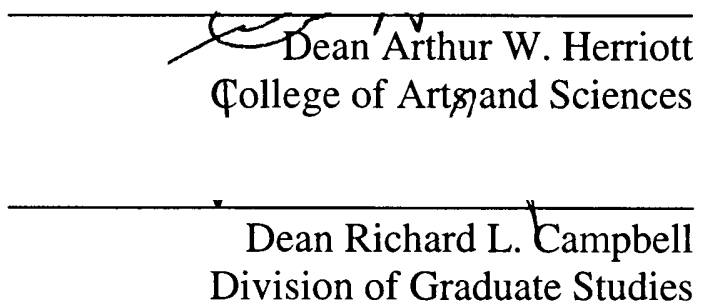

Florida International University, 2000 


\section{ACKNOWLEDGMENTS}

I would like to thank my committee for the guidance they provided in academic, technical, and personal issues, for their encouragement, and for their patience. I would especially like to thank Dr. Victor Apanius who spent countless hours at my side assisting me with all phases of this project. I would also like to thank Dr. James W.

Fourqurean for believing in me. Finally, I would like to thank my Mother whose guidance, patience and loving care helped me to fulfill this dream. 
THE DISTRIBUTION AND ABUNDANCE OF THE EXOTIC AND NATIVE URBAN AVIFAUNA IN MIAMI-DADE COUNTY FLORIDA

by

Omar Z. Abdelrahman

Florida International University, 2000

Miami, Florida

Professor Victor Apanius, Major Professor

Southern Florida is experiencing an unprecedented population expansion of several exotic avian species. To understand the impact of introduced species on the native bird community, I censused two transects that spanned older, urban, closed canopy (ca. 60 yr.old) to more recent ( $<20$ yr-old) suburban, open canopy habitats in Miami-Dade County, Florida for a 12-mo period. The recently introduced Eurasian Collared Dove (Streptopelia decaocto) was the most abundant species $\left(92.7 \mathrm{birds} / \mathrm{km}^{2}\right)$, but density varied across transects with lowest density $\left(2.87 \mathrm{birds} / \mathrm{km}^{2}\right)$ in older-growth habitat compared to the maximum density $\left(210 \mathrm{birds} / \mathrm{km}^{2}\right)$ in young habitat. The European Starling (Sturnus vulgaris) was second in abundance at $79.1 \mathrm{birds} / \mathrm{km}^{2}$. The Boat-tailed Grackle (Quiscalus major) was the third most abundant species $\left(67.5 \mathrm{birds} / \mathrm{km}^{2}\right)$. The Mourning Dove (Zenaida macroura), considered to be threatened by the Collared Dove (Simberloff et al. 1997, Schmitz and Brown 1994), was the next most abundant at (66.1 birds $/ \mathrm{km}^{2}$ ). The House Sparrow (Passer domesticus) was evenly distributed and 
consistently averaged 52.5 birds $/ \mathrm{km}^{2}$. The Rock Dove (Columba livia) averaged 39.7 birds $/ \mathrm{km}^{2}$ and was absent from older areas with high canopy cover. The Northern Mockingbird (Mimus polyglottos) averaged $34.5 \mathrm{birds} / \mathrm{km}^{2}$ and was the most evenly distributed species in the study area. The Blue Jay (Cyanocitta cristata) was also evenly distributed and averaged $16.9 \mathrm{birds} / \mathrm{km}^{2}$. The introduced Monk Parakeet (Myiopsitta monachus), considered an agricultural pest, averaged $9.70 \mathrm{birds} / \mathrm{km}^{2}$, with peak abundance in recently developed habitats $\left(22.8 \mathrm{birds} / \mathrm{km}^{2}\right)$ and none observed in older urban areas. The Red-bellied Woodpecker (Melanerpes carolinus) was consistently observed at $6.07 \mathrm{birds} / \mathrm{km}^{2}$. Introduced species are a numerically dominant component of the urban avifauna in Miami, composing over $53 \%$ of the resident bird population. 
TABLE OF CONTENTS

CHAPTER

PAGE

I. INTRODUCTION

Overview and significance

Invasion Dynamics

Study Area

4

II. METHODOLOGY 5

Census Method 5

Statistical Methods 6

III RESULTS $\quad 8$

Seasonal Pattern 9

$\begin{array}{ll}\text { Spatial Trend } & 9\end{array}$

IV DISCUSSION 12

Dispersion $\quad 12$

Seasonal Variation 14

Segment Difference 16

Habitat Differences $\quad 17$

Summary 19

Recommendations $\quad 20$

LIST OF REFERENCES $\quad 22$

$\begin{array}{ll}\text { APPENDICES } & 29\end{array}$ 


\section{LIST OF TABLES}

TABLE

PAGE

1. Means and Variances of Population Density....

2. Means and Variances Pooled by Month for the 10 Most Abundant Species

3. Means and Variances Pooled by Segment for the 10 Most Abundant Species.

4. Test Statistics for the Interaction Between Time and Month in the Analysis .28 of Density

5. Test Statistics for the Interaction Between Time and Segment in the Analysis .28 of Density

6. Test Statistics for the Month Effect in the Analysis of Density .28

7. Test Statistics for the Segment Effect in the Analysis of Density

8. Test Statistics for the Regional Effect in the Analysis of Density .29 
1. Map of Study Area..................................................... 30

2. Graphs of Cumulative Frequency for cutoff distance determination................. 31

3. Monthly Mean Density for Each Species.......................................32

4. Mean Segment Density of Collared Doves...................................33

5. Mean Segment Density of European Starlings..................................34

6. Mean Segment Density of Boat-tailed Grackles.................................35

7. Mean Segment Density of Mourning Doves.......................................36

8. Mean Segment Density of House Sparrows......................................37

9. Mean Segment Density of Rock Doves..................................... 38

10. Mean Segment Density of Northern Mockingbirds..............................39

11. Mean Segment Density of Blue Jays......................................40

12. Mean Segment Density of Monk Parakeets.......................................41

13. Mean Segment Density of Red-bellied Woodpeckers...........................42

14. Mean Density in Each Region (Habitat) ......................................43 


\section{INTRODUCTION}

Overview and Significance

Biological invasions are a major concern for conservation biologists because they can alter community composition and extirpate threatened species through competition, predation, or pathogen introduction (Pell and Tiedmann 1997). Unfortunately, the effects of invasive species on community processes are difficult to assess and often are observed after permanent changes have occurred. Currently $20 \%$ of the world's endangered vertebrates are considered to be threatened by exotic species (Baskin 1996).

Temple (1992) estimated that there are 97 introduced species with stable or increasing populations in the United States. Of these $26 \%$ are from the Neotropics, $47 \%$ from Eurasia, 22\% from Africa, and 4\% from elsewhere. Baskin (1996) estimated that $20 \%$ of introduced avian species cause serious economic damage. According to Temple (1992), $56 \%$ of the introduced species are harmful ecologically or economically, $5 \%$ are beneficial to the community, and $39 \%$ have mixed impacts.

Invasion Dynamics

Species are usually introduced through accidental or intentional release of exotic pets, biological control agents, or attempts to provide alternative game for hunting (Brown 1997). The vast majority of species introductions fail. As a general rule only one in ten introductions become established and only one in ten of those become pests (Williamson and Fritter 1996). It is thought that most introduced species become established in disturbed areas that have low biotic resistance from competition, lack of predators, and lack of pathogens (Chapuis et al. 1991, Duncan 1997, Lockwood et.al. 1993, Moulton and Sanderson 1997, Smallwood 1994). The number of introduction 
attempts and the number of individuals released appear to be the most important factors which determine the success of introductions. Finally, small genome size, short juvenile period, and short generation times lead to increased invasive success in plants, and could also apply to vertebrates, but more investigation of these properties in vertebrates is needed (Baskin 1996). Similarly, the importance of human modification of natural habitats in determining the outcome of species introductions remains to be assessed.

As urban and suburban landscapes continue to expand, their effects on wildlife population dynamics need to be understood in order to effectively design and manage these landscapes for wildlife species. Several studies have focused on the relationship between urbanization and bird diversity and abundance (Emlen 1974, Landcaster and Rees 1979, Mills et al. 1989, McDonnell and Pickett 1990, Blair 1996, Bolger et al. 1997, Clergeau et al. 1998). The studies noted that increased urbanization is associated with decreased species diversity and increased abundance of particular species that are able to thrive in urban habitats. Some bird species may only tolerate urban environments with moderate densities in urban areas, while certain species seem to avoid urban habitats and are mostly observed in surrounding natural habitats. Human activity can modify (1) structural habitat complexity (i.e. through construction and landscaping), (2) resource availability, such as bird feeders, pet food, water baths, garbage, and (3) environmental conditions, such as air pollution, noise, and toxic chemicals.

For the past three decades South Florida has experienced an unprecedented population expansion of several exotic avian species including Eurasian Collared Doves (Streptopelia decaocto), European Starlings (Sturnus vulgaris), House Sparrows (Passer domesticus), Rock Doves (Columba livia), Monk Parakeets (Myiopsitta monachus) and 
others (Stevenson and Anderson 1994, Owre 1973). In Florida, 9\% of avian species are established exotic species whereas the national average is less than $5 \%$ (Temple 1992). My study is the first to document the avian community of urban Miami-Dade County, including introduced species. My study was designed to determine the numerical importance of introduced species and to assess the sources of variation in their abundance. This study is also the first to show the extent to which exotic species have established themselves in urban Miami-Dade County in the context of community composition. These data can be used in the future to follow the changes in the avian community over time as urban development further reduces the remaining natural upland habitat.

Among the sources of variation I examined were differences in the species abundance from older urban areas to more recent suburban developments. This variation in abundance may be attributable to the maturation of horticultural landscaping, because in certain older urban areas of Miami-Dade County the canopy cover is more extensive and diverse than it is in newer housing developments. Diversity of introduced avian species is known to increase as the age of urban habitats increases (Veltman 1996, Smallwood 1994, Greig-Smith 1986) because disturbance removes native species and creates new ecological opportunities. I also examined seasonal variation in species abundance which may be attributable to the influx of migrant birds during the spring and autumn. The coastline of peninsular Florida and the Florida Keys are known to concentrate migrating populations. Whether these seasonal concentrations occur in urban Miami has not been determined. 
Study Area

Pinelands, sawgrass prairie, and tropical hammocks historically covered extreme south Florida except for a few coastal ridges and beaches (Snyder et.al. 1990).

Mangroves (Rhizophora mangle, Avicennia germinans, and Laguncularia racemosa) and buttonwood (Conocarpus erectus) originally dominated coastal areas, but development resulted in the removal of thousands of acres of mangrove forests (Odum and McIvor 1990). The human settlement of South Florida began in the coastal eastern edge of Miami-Dade County, along the coastal limestone ridge, and expanded westward. Landscaping activities and the passing of time have resulted in a general trend toward greater canopy development and plant diversity in the eastern part of the county than in the west. This is especially notable in affluent Coral Gables, where an artificial forest-like habitat has been created in some places. The urban Miami flora is a combination of introduced and native trees. Fruit trees, Black Olive (Budica buceras), Brazilian Pepper (Schinus terebinthifolius), and Australian Pine (Casuarina equestefolia) are perhaps the most common introduced species. Western Miami-Dade County was once primarily agricultural, but human population growth has increasingly claimed the agricultural lands and altered much of that landscape into a suburban residential zone. A notable exception is a region just west of Florida's Turnpike called Horse Country where small, diversified residential farms remain, including riding stables and plant nurseries.

I divided the study area into 5 regions (Fig. 1). At the eastern margin (Region I), the oldest (developed before 1962) and most densely populated urban habitat has scattered trees. To the west is Coral Gables (Region II) with the highest canopy and lowest building density. Continuing west is Westchester (Region III), which was 
developed from 1963-1969 with moderate canopy development. The westernmost area is unincorporated Miami-Dade (Region IV) the most recently developed region (19761979) with sparse canopy and higher building density than Westchester or Coral Gables. Within Region IV is the sub-region called Horse Country (Region V) described above.

\section{METHODS}

Census Method

From May 5, 1998 to May 2, $1999 \mathrm{I}$ bicycled at approximately $10 \mathrm{~km} / \mathrm{hr}$ and counted birds along two 12 mile $(19.2 \mathrm{~km})$ transects. Each 12 mile transect was further divided into 1 mile $(1.61 \mathrm{~km})$ segments which traverse central Miami-Dade county (Fig. 1). I recorded the species detected by sight or song and the perpendicular distance from the transect to the birds. From May to December 1998 I sampled each transect twice weekly, as weather permitted. I executed each sampling effort at one of three time periods: (1) morning up to one hour after sunrise, (2) midday, and (3) evening until sunset. I rotated the sampling schedule so that each segment was sampled at different times of the day. From 1 January to 2 May 1999, I sampled only in the morning and sampled each transect once per week. Each segment took approximately 7 minutes to complete.

I established a species-specific detectability cutoff distance from graphs of cumulative frequency vs. distance (Emlen 1974, Blair 1996, Bolger er al. 1997, Fig. 2). The cutoff was set at the point of steepest slope beyond which less than $50 \%$ of the detection frequencies occurred (Fig. 2). From this I estimated the species densities by 
using the counts of birds within that perpendicular cutoff distance divided by the product of segment length and twice the cutoff distance (count/area).

\section{Statistical Methods}

In order to determine if population density was more heterogeneous in space than in time I computed the variance of density when the data were pooled either by month or by segment (of transect). If the month-pooled variance is greater than the segment-pooled variance, then seasonal heterogeneity is greater than spatial heterogeneity. If the segmentpooled variance is greater than month-pooled variance then spatial heterogeneity is greater than seasonal changes. I also compared the observation frequency for each species and I decided to focus on the distribution of the ten most common species for further analyses.

Census (count) data are poisson distributed if extraneous sources of variation, such as temporal or geographic heterogeneity are negligible. If individuals are not randomly distributed, but rather aggregated in either space or time, then the data are said to be overdispersed. In that case the distribution is similar to a negative binomial and the mean is no longer equal to the variance. Instead the variance is equal to the mean multiplied by an overdispersion parameter which is a relative measure of aggregation (Crawley 1993, Zar 1998). Overdispersion can be verified by a variance to mean ratio greater than one (Crawley 1993, Zar 1998). For the ten most abundant species, I investigated the density variance-to-mean ratio when the data were pooled by month or segment in order to assess the underlying distribution of the data. I modeled the variance as a function of the mean using regression analysis (see Results). The data have variance- 
to-mean ratios greater than one and a significant positive linear regression of the variance on the mean, thus inferences about the density of the ten most common species required statistical models based on an overdispersed poisson distribution.

I modeled the densities of the ten most abundant species by using PROC GENMOD (SAS v.6.12, SAS Institute Cary, NC) to test for significant differences in density due to time of day, month, segment, and region, as well as the interaction between these factors. The GENMOD procedure fits generalized linear models to the data by maximum likelihood estimation. The GENMOD procedure estimates the overdispersion (or scale) parameter (a measure of the degree of aggregation) from the data and uses it in a log-link function to model the data to a specified distribution. It does so by scaling each term in the variance-covariance matrix by the scale parameter. Since there was no interaction between spatial effect and seasonal effect, the spatial analyses were adjusted for the sampling month by using type 1 sum of squares, which partitions the variance of each factor sequentially and allows factors to be used as covariates for statistical control. The GENMOD procedure reports both F-ratio and chi-square tests of significance along with estimates of the statistics for each level of each factor in the model. Each significance test yielded nearly identical results so only F statistics are reported here. The GENMOD procedure reports the goodness of fit test as a chi-square distributed parameter. Non-significant values indicate that the model has been properly specified. In order to test for differences between habitat types, I first had to test for difference between the two transects which traversed each habitat. I used a paired sample t-test where I paired segments in the northern transect with segments of similar longitudes in the southern transect. 


\section{RESULTS}

All results are reported in order of species abundance. For the t-test comparison between the two transects the only species that differed significantly between transects were the Rock Dove $(\mathrm{t}=2.978 \mathrm{P}=0.0046)$, Blue Jay $($ Cyanocitta cristata $)(\mathrm{t}=4.065$ $\mathrm{P}=0.0002)$ and Monk Parakeet $(\mathrm{t}=3.579 \mathrm{P}=0.0008)$.

The observed avian species are listed by frequency of observation in Table 1 . The birds most frequently observed were generally the most abundant. For the majority of species $(17 / 23=74 \%)$ the segment-pooled variance was greater than the month-pooled variance (Table 1). In an F-test of the variances, monthly variance and spatial variance were not significantly different for 7 of 23 species (Table 1). Thus, for most species, density was significantly more variable on a spatial scale compared to seasonal variation in density. The spatial and seasonal variation in density were indistinguishable (Table 1) for the Northern Mockingbird (Mimus polyglottos), Blue Jay, American Kestrel (Falco sparvarius), unidentifiable passerine, unidentifiable species, Palm Warbler (Dendroica palmarum), and Purple Martin (Progne subis).

The regressions of the mean on the variance of the month-pooled density data (Table 2) were significant for all species except the Mourning Dove (Zenaida macroura). When the data were pooled by segment the regressions of the mean on the variance (Table 3) were significant for all species except the Northern Mockingbird, and this was nearly significant. These analyses show that the density variance is a linear function of the mean density for most species and that these data conform to the distributional assumptions of the overdispersed poisson regression model. 
For the first 6 months of this study when transects were sampled at three different times in the day, early morning, midday, and afternoon, there was a significant interaction (Table 4) between sample time and month for the Mourning Dove, House Sparrow, Northern Mockingbird, and Blue Jay. This interaction suggests that the seasonal effect could not be separated from the sample time effect. Similarly, there was a significant interaction between time and segment for those same four species (Table 5), which indicates that the spatial effect is also confounded with the sample time effect. For those species with significant time of day interactions I included only the morning samples for further analyses. For the other species, sampling time was treated as a covariate in the model.

Seasonal pattern

There was a significant difference in mean monthly density for every species except the Monk Parakeet and the Red-bellied Woodpecker (Table 6) and for the all species summed together (total bird density; not shown). There were three discernable and statistically demonstrable trends of seasonal abundance (Fig. 3). First, birds were less abundant in March through June and more abundant, though possibly fluctuating, throughout the rest of the year. The Eurasian Collared Dove, European Starling, Boattailed Grackle (Quiscalus major), Rock Dove, and possibly the Monk Parakeet showed this trend. The second trend includes species which seemed to be abundant in May through September and were low in abundance from November to February. The House Sparrow and Northern Mockingbird displayed this pattern of seasonal abundance. Mourning Doves and Blue Jays appeared to be less abundant from March to May, and again from October to January compared to the rest of the year. The Red-bellied 
Woodpecker did not show any discernable seasonal changes in abundance, but they were so scarce that any trend would have been difficult to detect.

Spatial Trend

For each of the ten most abundant species mean density in each segment of the northern and southern transects are depicted in order of abundance (Fig. 3-12).

Abundance was significantly different across segments for all species (Table 7). The Eurasian Collared Dove had lowest densities in Coral Gables $\left(80^{\circ} 15-17.3^{\prime}\right.$ in Transect 1 and $80^{\circ} 15.5-17.5^{\prime}$ in Transect 2; Fig. 4). The Collared Dove had highest densities in the western segments with a notable peak of $400 \mathrm{birds} / \mathrm{km}^{2}$ in one segment (e.g. Horse Country, $\left.80^{\circ} \approx 25.5^{\prime}\right)$. There were somewhat lower peaks in the more urbanized areas in Transect $1\left(80^{\circ} 13.0^{\prime}\right)$ and in Transect $2\left(80^{\circ} \approx 18.4^{\prime}\right)$.

European Starling density was lowest in westernmost segments $\left(80^{\circ} 23.0^{\prime}\right)$ and Coral Gables in Transect 1 (Fig. 5). In Transect 2, starling density was highest in Coral Gables and lowest in the westernmost segment $\left(80^{\circ} 25.0^{\prime}\right)$.

The Boat-tailed Grackle had the lowest density in Coral Gables. In both transects grackle density was generally higher west of $80^{\circ} 17.5^{\prime}$ (Fig.6) with the highest density in Transect 2 at $80^{\circ} 22.7^{\prime}$.

Mourning Doves had the highest density east of Coral Gables in Transect $1\left(80^{\circ}\right.$ $\left.14.7^{\prime}\right)$ and in the segment immediately to the west of Coral Gables $\left(80^{\circ} 18.6^{\prime}\right)$ in Transect 2 (Fig. 7). Mourning Doves had consistently lower density in all other segments.

House Sparrow density was highly variable across the study area (Fig. 8). House Sparrows were abundant in the eastern edge of Coral Gables in Transect $1\left(80^{\circ} 14.5^{\prime}\right)$. 
House Sparrows were also abundant in the west-central segments in Transect $1\left(80^{\circ}\right.$ $\left.\approx 21.1^{\prime}\right)$ and in Transect $2\left(80^{\circ} \approx 18^{\prime}\right.$ and $\left.22.5^{\prime}\right)$.

Rock Dove density varied considerably across segments (Fig. 9), but this species was found in consistently low densities in Coral Gables. Significantly higher densities were observed in 4 segments that were widely spaced across the two transects.

Northern Mockingbird density was consistent across segments, although significant differences between segments were detected (Fig. 10). Mockingbird density showed a modest peak in the central segments $\left(80^{\circ} 18.2^{\prime}\right)$ of both transects.

Mean density of Blue Jays and Red-bellied Woodpeckers was consistent between transects (Fig.11 and Fig. 13 respectively). Blue Jays, and possibly Red-bellied Woodpeckers, had their highest densities in Coral Gables.

Monk Parakeets were most abundant in two particular segments $\left(80^{\circ} \approx 14.5^{\prime}\right.$ and $80^{\circ} \approx 20.4^{\prime}$ ) of Transect 1 (Fig. 12). The density of Monk Parakeets was consistently low in Transect 2.

The population density in the 5 different habitat types is presented in Figure 14 and results from statistical analyses are summarized in Table 8. The Eurasian Collared Dove was exceedingly abundant in Horse Country (Region V), with lowest densities in Coral Gables (Region II) and eastern Miami (Region I). Boat-tailed Grackle density was highest in Regions III and IV, and lowest in Region I. European Starling density was highest in Region III and lowest in Regions IV and V, but the analysis found no significant difference in density among regions (Table 8). Mourning Doves density was highest in Region I, and monotonically decreased in the west. House Sparrow density 
was highest in the easternmost region (Region I) followed by Region III and then Horse Country. Northern Mockingbird density did not differ significantly among regions. Rock Dove density was also highest in the easternmost urban area (Region I) while Horse Country had the lowest density of Rock Doves. Blue Jays were most abundant in Coral Gables (Region II) and least abundant in the recently developed habitat (Region IV). Monk Parakeet density did not differ significantly between regions. Red-bellied Woodpecker density was highest in Coral Gables and East Miami. Although the regional difference in Red-bellied Woodpecker density was statistically significant, the magnitude of this difference was small.

\section{DISCUSSION}

In South Florida introduced species dominate the urban landscape except where tree canopy is extensive. In amply vegetated landscapes native species are more abundant and more species, particularly passerines, are present, though overall bird density was higher in the oldest more urbanized areas. Researchers noted similar patterns in Tucson, Arizona, USA (Emlen 1974 and Mills et al. 1989), multiple locations throughout California, USA (Smallwood 1994), Santa Clara, California, USA (Blair 1996), Finland (Jokimaki et al. 1996), and in Quebec City, Canada and Rennes, France (Clergeau et al. 1998).

Comparison of the variances when pooled by month versus pooled by segment suggests that for most species more of the observed variation was attributable to spatial rather than seasonal factors (Table 1). Variances in densities of Northern Mockingbirds, Blue Jays, American Kestrels, White-winged Doves (Zenaida asiatica), and Red-bellied 
Woodpeckers were not significantly different among segments, but much of this is likely due to low power from high variation rather than lack of a spatial effect. Some species are semi-migratory and have a resident population in addition to migratory individuals. White-winged Doves, Red-bellied Woodpeckers, European Starlings, and possibly Blue Jays have a resident population and some migrant individuals. In addition, species like the Northern Mockingbird and Blue Jay are territorial and may be somewhat evenly distributed in space, so seasonal variation would likely be greater than spatial variation. Northern Mockingbird spatial evenness was probably due to territoriality, which is indicated by the low scale parameter (estimate of overdispersion) of 2.3 compared to the range of 4-8 for the other species and the insignificant regression of the variance to mean density when the data were pooled by segment (Table 3 ). Conversely, an assumption of a random spatial distribution for Rock Doves may not be justified, because they associate in large flocks and roosting/nesting colonies, and have a scale parameter of 7.7. Because of flocking, one could expect to see many individuals at once whenever they are present, but few to none in most other locations. Monk Parakeets also flock, advertise their presence vocally, and have conspicuous colonial nests. The densities of both these species were significantly different between the two transects in each habitat. Other species may also flock, but their large-scale distribution is not as patchy as that seen in Rock Doves and Monk Parakeets.

The interaction between time and space for certain species may result from the feeding schedule of the livestock caretakers in Horse Country, as in the case of the granivorous House Sparrow. The shading effects of dense canopy cover made the midday climate during the summer months more favourable to activity in Coral Gables 
where it was more likely to observe Mourning Doves, House Sparrows, Northern Mockingbirds, and Blue Jays during the midday than at other locations. Mourning Doves often roost in large numbers at specific locations and change to new roosting sites over time (personal observation), which would explain why their densities would simultaneously differ in time and space.

The interaction between time and month may be associated with varying day length. As day length increases birds can wait until later to forage or they can forage longer. In winter months birds must complete foraging before complete darkness at 18.00 h.

The European Starling, Mourning Dove, and Rock Dove may show some influence of migration or other seasonal trends by an increase in abundance in late fall through late winter. Eurasian Collared Doves and Boat-tailed Grackles are also abundant in winter months with a notable increase in density from December to February, but fall abundance was similar to winter abundance in both species, so migration may not totally explain the seasonal patterns of collared doves and grackles. This seasonal trend in abundance is particularly interesting for the Eurasian Collared Dove, because they are recently introduced and expanding their range throughout North America and their life history is not well known. The seasonal difference in Eurasian Collared Dove abundance may not result from migration effects but from the annual breeding cycle. I interpret the depression in abundance in April through June to be associated with egg incubation period when these birds may be spending most of the time on nests. The sharp increase in abundance in July is probably due to early recruitment and adults gathering food for nestlings, and then the steady increase from August to November may be due to 
recruitment from reproduction. The peak abundance of European Starlings in January and February suggest that northern migrants contribute substantially to the winter population. Mourning Dove seasonal abundance was similar to both the Eurasian Collared Dove and the European Starling, but density decreased more dramatically from October to December. The decline in Mourning Dove abundance from September through December might be either due to juvenile mortality or migration while the increase in January and February suggests migrants are arriving. Schultz et al. (1996) found that in Missouri, spring and summer were periods of low mortality in Mourning Doves. Although Missouri is geographically dissimilar from Florida, summer environmental conditions may be similar. Therefore, I suggest that my low numbers during March through June was likely due to nesting behaviour.

The relatively moderate difference in abundance across the year for some species is probably attributable to the sub-tropical study area where the species of focus are yearround residents, but some individuals do migrate from temperate areas. The migrants may be fewer compared to year-round residents and might not contribute as much to the population abundance as in species with populations of strictly northern migrants. Another possibility is that established residents, who are familiar with the territory and its available resources, competitively exclude non-residents. I collected no data distinguishing migrant individuals from year-round residents so I cannot provide conclusive evidence about the degree to which migrants contribute to bird densities.

The data from this study seem to support my presupposition that during the breeding season birds incubating clutches would lead to a reduced frequency of observation and observations with fewer individuals. During incubation birds need to 
forage to meet their daily energy requirements and may realize an increased energetic demand from heat transfer to the eggs. Brooding individuals must balance foraging time with incubation time, so unless the mating system is one in which the non-brooding mate (usually the male) provides for the brooding mate, the foraging activity will remain the same or more likely become more time efficient due to seasonal increase in food availability. The trend of lower density in April and/or May for Eurasian Collared Doves, Starlings, Boat-tailed Grackles, Mourning Doves, House Sparrows, Rock Doves, Blue Jays, and Monk Parakeets could be because these species are either granivoures or omnivoures. If food sources are seasonally more abundant, there may be some effect in observed abundance during this breeding season because these species are able to meet their energy requirements in less foraging time.

High density of the introduced Starling, Rock Dove, and Eurasian Collared Dove in the easternmost and most urbanized part of the county is typical of urbanized areas where introduced species thrive (Emlen 1974, Mills et al. 1989, Smallwood 1994, Blair 1996, Jokimaki et al. 1996, Clergeau et al. 1998). Surprisingly, Mourning Dove density was also high in the urban area, even higher than Eurasian Collared Doves $(23.78 \pm 2.53$ compared to $11.42 \pm 2.57$ ) in this area. The habitat in the eastern region is relatively diverse, and granivores, like the Mourning Dove, are often subsidized by bird feeders. The Boat-tailed Grackle, an ecologically diverse species in south Florida, often found foraging on human discards, was the second most abundant native in the east section. Other native species were virtually nonexistent in the east, and most of their observations came from small pockets of moderate to dense canopy within the area. 
Generally, the density of all species was lower in the well-developed canopy habitat of Coral Gables, but the densities of introduced species were also lower relative to natives in this area with the exception of Starlings and the House Sparrow in Transect 1. Detectability could be impaired in areas of high vegetation cover since cryptic arboreal species are more difficult to see. In Transect 2 of Coral Gables, Mourning Dove density was the third highest compared to all other segments in the entire study area, without considering the effect of detectability, and second to the European Starling in abundance. Mourning Doves, which are considered to be threatened by the Eurasian Collared Dove (Simberloff et al. 1997, Schmitz and Brown 1994), were much more abundant in areas where Eurasian Collared Dove density was low. Generally throughout the entire study area Mourning Dove density was negatively associated with Eurasian Collared Dove density, which may suggest habitat preference or spatial differences in food availability, but it may also suggest competition between these two species. Densities of European Starling in the southern transect of Region II through Coral Gables may be high because the eastern segment is directly adjacent to a highly urbanized area without any transition zone, so the birds may be coming from these adjacent areas. Also European Starlings are generalists which can exploit many resources and habitat types. House Sparrow increase in Transect 1 of Coral Gables may be due to two point sources where small colonies nest in the roofs of two homes in that area. Frequent encounters of few individuals, rather than many individuals, may account for the calculated high density. Rock Doves were also less abundant in the dense canopy area of Coral Gables, but sharply increased in the two segments directly east and west of Coral Gables. In fact, their abundance in Coral Gables may be even lower than the data indicate. They were never observed in the interior of 
Coral Gables and were only seen at both ends (edges) of that habitat, where they were probably just transient into the adjacent habitat. Blue Jay density increased significantly in the well-developed canopy habitat, whereas Red-bellied Woodpecker density increased in the same Region but the increase was not numerically significant.

The central region of both transects had a moderately dense canopy and supported high densities of introduced species, particularly Eurasian Collared Doves, compared to native species. In the central region the versatile Boat-tailed Grackle was very abundant, but the density of Mourning Doves was lower. The increase in Monk Parakeet abundance in the central and the western region suggests that they prefer open areas. In a description of Monk Parakeet biology and species attributes, Forshaw (1989) and Bucher (1991) state that they are mainly found in open, park-like areas of South America.

The Horse Country area was interesting in that Eurasian Collared Doves were eight times more numerous than the next most abundant species (Boat-tailed Grackle). This abundance of collared doves is most likely due to food subsidy from livestock feed, which also explains the increase in the abundance of House Sparrows, which were commonly observed foraging in the livestock feeding stations along with collared doves. Horse Country may also serve as a source from which birds disperse to neighboring areas, similar to dispersions of Florida Scrub Jay populations in central Florida (Bowman, personal communication, Bowman cited in Blair 1996), since adjacent segments had high densities of these species.

Although Boat-tailed Grackles and European Starlings were more numerous than most other species in the entire study area, the abundance of both species was lower in Horse Country compared to Regions III and IV. I doubt that starlings and grackles exploit 
livestock feed to the same extent as the Eurasian Collared Dove and the House Sparrow. In the segment west of Horse Country, House Sparrow and Eurasian Collared Dove abundance decreased to numbers which are characteristic of surrounding Region IV.

Surprisingly, Red-bellied Woodpecker density varied little among transects and they were relatively rare across the entire study area. I expected them to favor dense canopy areas with more trees for nest building in tree cavities and vegetation-dependent insects. Standing dead wood is considered hazardous and unattractive in well-manicured artificial landscapes, so it is likely to be removed. The low abundance of Red-bellied Woodpeckers throughout the study area can be attributed to their insectivorous diet or limited availability of dead wood for nest cavities.

In conclusion, the human modified landscapes of Miami-Dade County host four introduced species: the Eurasian Collared Dove, European Starling, House Sparrow, and Rock Doves. These are more abundant than all native species except the Boat-tailed Grackle. In contrast, the dense canopy area of Coral Gables has lower densities of introduced species, with exception of the European Starling and the seed subsidized House sparrow.

I did not compare my study area with natural habitats, because very few of these areas still exist in Miami-Dade County, and they exist only in small pockets surrounded, and thus influenced, by human-modified areas. Additionally, the bicycle survey technique could not be used in natural areas unless they contained a good trail or road system. The closest area of appreciable size, which fits this description, is Everglades National Park, which is so far from the study area that any comparisons would be irrelevant. Investigation of the small, relatively natural areas may contribute valuable 
information to this study, even though conclusions may be subject to criticism because the effect of a small study area may be confounded with habitat attributes.

Additional studies in subsequent years are also needed to conclusively validate the inferences made in this study. This study was performed during a La Niña year; so weather patterns may have affected the populations and the behavior of individuals.

The idea that Monk Parakeets will cause widespread economic damage, or competitively displace native species is unwarranted. Their abundance is low compared to other birds, and their distribution seems limited to small pockets of habitat with appropriate nesting substrates. I surveyed Miami-Dade County's agricultural area for nest sites and found only 3 sites with a maximum of 2 nests at any site. The Eurasian Collared Dove and the European Starling are of greater concern, because starlings openly confront other species, even aggressive, territorial species, such as Northern Mockingbirds (personal observation), and take over nest cavities of woodpeckers (Kerpez and Smith 1990, Ingold 1989, Ingold 1990, Weitzel 1988) and Purple Martins (personal observation). Nillson (1984) found that breeding success of Great Tits (Parus major) and Nuthatches (Sitta europaea) declined because European Starlings usurped them from nest cavities. Weitzel (1988) drew similar conclusions while studying how starlings affect native species in Nevada. I have also witnessed Eurasian Collared Doves attacking Boattailed Boat-tailed Grackles and Mourning Doves. These behaviors will allow native species to be displaced through interference and resource competition. These introduced species need to be monitored over time in order to whether they are expanding their range into natural areas and if they are displacing native species. If native species abundance 
continues to decline as these introduced species increase in number, natural resource agencies may eventually need to control these species. 


\section{LITERATURE CITED}

Baskin, Y. (1996). “Curbing undesirable invaders.” Bioscience, 46, 732-736.

Blair , R. B. (1996). "Land use and avian species diversity along an urban gradient." Ecological Applications, 6, 506-519.

Bolger, D. T., Scott, T. A., and Rotenberry, J. T. (1997). "Breeding bird abundance in an urbanizing landscape in coastal Southern California." Conservation Biology, 11, 406-421.

Brown, T. C. (1997). "The State's Role". in Strangers in Paradise, (Simberloff, D., Schmitz, D. C., and Brown, T. C., editors). Island Press, Washington, D.C.

Bucher, E. H. (1991). "Neotropical parrots as agricultural pests". in New World Parrots in Crisis: Solutions from Conservation Biology. (Beissenger, S. R., Snyder, N. F. R. editors) Smithsonian Institution Press, Washington, DC.

Chapuis, J. L., Bousses, P., and Barnaud, G. (1994). “Alien mammals, impact and management in the French subantarctic islands." Biological Conservation, 67, 97-104.

Clergeau, P., Savard, J. L., Mennechez, G., and Falardeau, G. (1998). "Bird abundance and diversity along an urban-rural gradient: a comparative study between two cities on different continents." Condor, 100, 413-425.

Crawley, M. J. (1993). Glim for Ecologists, Blackwell Science, Inc., Cambridge Massachusetts.

Duncan, R. P. (1997). "The role of competition and introduction effort in the success of passeriform birds introduced to New Zealand." American Naturalist, 149, 903-915.

Emlen, J. T. (1974). "An urban bird community in Tucson, Arizona: derivation, structure, regulation." Condor, 76, 184-197.

Forshaw, J. M. (1989). Parrots of the World, Landsdowne, Melbourne, Australia.

Greig-Smith, P. W. (1986). "The distribution of native and introduced landbirds on Silhouette Island, Seychelles, Indian Ocean.” Biological Conservation, 38, 35-54.

Ingold, D. J. (1989). "Nesting phenology and competition for nest sites among Redheaded and Red-bellied Woodpeckers and European Starlings." Auk, 106, 207-217.

Ingold, D. J. (1990). "Simultaneous use of nest trees by Red-headed and Red-cockaded Woodpeckers and European Starlings." Condor, 92, 252-253.

Jokimaki, J., Suhonen, J., Inki, K., and Jokinen, S. (1996). “Biogeographical comparison 
of winter bird assemblages in urban environments in Finland." Journal of Biogeography, $23,379-386$.

Kerpez, T. A., and Smith, N. S. (1990). "Competition between European Starlings and native woodpeckers for nest cavities in Saguaros." Auk, 107, 367-375.

Lancaster, R. K., and Rees, W. E. (1979). "Bird communities and the structure of urban habitats." Canadian Journal of Zoology, 57, 2358-2368.

Lockwood, J. L., Moulton, M. P., and Anderson, S. K. (1993). "Morphological assortment and the assembly of communities of introduced passeriforms on oceanic islands: Tahiti versus Oahu." American Naturalist, 141, 399-408.

McDonnell, M. J., and Picket, S. T. A. (1990). "Ecological system structure and function along urban-rural gradients: an unexplored opportunity for ecology." Ecology, 71, 12321237.

Mills, G. S., Dunning, J. B., and Bates, J. M. (1989). "Effects of urbanization on breeding bird community structure in southwestern desert habitats." Condor, 91, 416-428.

Moulton, M. P., and Sanderson, J. G. (1997). "Predicting the fates of passeriform introductions on oceanic islands." Conservation Biology, 11, 552-558.

Nillson, S. G. (1984). "The evolution of nest -site selection among hole-nesting birds: the importance of nest predation and competition." Ornis Scandinavia, 15, 167-175.

Odum, W. E., McIvor, C. C. (1990) Mangroves. In Ecosystems of Florida (Myers, R. L., Ewel, J. J. editors) University of Central Florida Press, Orlando, Florida.

Owre, O. T. (1973). A consideration of the exotic avifauna of southeastern Florida.Wilson Bulletin, 85,491-500.

Pell, A. S., and Tidemann, C. R. (1997). "The impact of two exotic hollow-nesting birds on two native parrots in savannah and woodland in eastern Australia." Biological Conservation, 79, 145-153.

SAS Institute Inc. (1997). SAS:STAT Software: Changes and enhancements through release 6.12, SAS Institute Inc., Cary, North Carolina.

Schmitz, D. C., and Brown, T. C. (1994). An assessment of invasive non-indigenious species of Florida's public lands, Florida Department of Environmental Protection, Tallahassee, Florida.

Schultz, J. H., Drobney, R. D., and Sheriff, S. L. (1996). "Adult Mourning Dove survival during spring/summer in northcentral Missouri." Journal of Wildlife Management, 59, 
Simberloff, D., Schmitz, D. C., and Brown, T. C. (1997). Strangers in Paradise, Island Press, Washington, D.C.

Smallwood, K. S. (1994). "Site invasibility by exotic birds and mammals." Biological Conservation, 69, 251-259.

Snyder, J.R., Herdon, A., Robertson, W.B. (1990). South Florida Rocklands. In Ecosystems of Florida (Myers, R. L., Ewel, J. J. editors) University of Central Florida Press, Orlando, Florida.

Stevenson, H. M., and Anderson, B. H. (1994). The Birdlife of Florida, University Presses of Florida, Gainesville, Florida.

Temple, S. (1992). "Exotic birds: a growing problem with no easy solutions" Auk, 109,395-397.

Veltman, C. J., Nee, S., and Crawley, M. J. (1996). "Correlates of success in exotic New Zealand birds." American Naturalist, 147, 542-557.

Weitzel, N. H. (1988). "Nest site competition between European Starlings and native breeding birds in northwest Nevada." Condor, 90, 515-517.

Williamson, M., and Fritter, A. (1996). "The varying success of invaders.” Ecology, 77, 1661-1666.

Zar, J. H. (1998). Biostatistical Analysis, Prentice Hall, New Jersey. 
Table 1. Density and comparison of the variation when pooled by month vs. by segment. Species are presented in order of observation frequency.

\begin{tabular}{|c|c|c|c|c|c|}
\hline Species & $\begin{array}{l}\% \text { Days } \\
\text { Observed }\end{array}$ & $\begin{array}{c}\text { Density } \\
\left(\text { Birds } / \mathrm{km}^{2}\right)\end{array}$ & $\begin{array}{c}\text { Variance } \\
\text { Pooled by segment } \\
\end{array}$ & $\begin{array}{c}\text { Variance } \\
\text { Pooled by month }\end{array}$ & $\mathrm{P}^{*}$ \\
\hline $\begin{array}{l}\text { Northern Mockingbird } \\
\text { Mimus polyglottos }\end{array}$ & 99.3 & 34.71 & 75.17 & 93.63 & 0.683 \\
\hline $\begin{array}{l}\text { Eurasian Collared Dove } \\
\text { Streptopelia decaocto }\end{array}$ & 98.0 & 95.33 & 10050.47 & 467.30 & 0.00000 \\
\hline $\begin{array}{l}\text { Boat-tailed Grackle } \\
\text { Quiscalus major }\end{array}$ & 97.8 & 69.15 & 1413.63 & 300.49 & 0.00545 \\
\hline $\begin{array}{l}\text { Mourning dove } \\
\text { Zenaida macroura }\end{array}$ & 97.0 & 68.49 & 1168.94 & 429.04 & 0.0441 \\
\hline $\begin{array}{r}\text { European Starling } \\
\text { Sturnus vulgaris }\end{array}$ & 96.5 & 83.19 & 2087.09 & 636.70 & 0.0227 \\
\hline $\begin{array}{l}\text { Rock Dove } \\
\text { Columba livia }\end{array}$ & 96.3 & 40.20 & 2178.29 & 138.73 & 0.00002 \\
\hline $\begin{array}{l}\text { Blue Jay } \\
\text { Cyanocitta cristata }\end{array}$ & 89.6 & 16.98 & 81.57 & 47.34 & 0.175 \\
\hline $\begin{array}{l}\text { House sparrow } \\
\text { Passer domesticus }\end{array}$ & 86.3 & 54.37 & 2162.78 & 514.07 & 0.00824 \\
\hline $\begin{array}{l}\text { Monk Parakeet } \\
\text { Myiopsitta monachus }\end{array}$ & 78.4 & 9.60 & 148.82 & 19.33 & 0.00006 \\
\hline Other $^{* *}$ & 71.4 & 2.85 & 9.36 & 1.48 & 0.00152 \\
\hline $\begin{array}{l}\text { Red-bellied Woodpecker } \\
\text { Melanerpes carolinus }\end{array}$ & 68.7 & 6.13 & 16.23 & 4.30 & 0.0132 \\
\hline $\begin{array}{l}\text { American Kestrel } \\
\text { Falco sparvarius }\end{array}$ & 68.1 & 1.44 & 1.44 & 1.28 & 0.439 \\
\hline $\begin{array}{l}\text { Unidentifiable passerine } \\
\text { - }\end{array}$ & 58.5 & 19.49 & 132.45 & 382.19 & 0.983 \\
\hline
\end{tabular}


Table 1 continued

\begin{tabular}{llllll}
\hline $\begin{array}{l}\text { White-winged Dove } \\
\quad \text { Zenaida asiatica }\end{array}$ & 58.4 & 9.78 & 228.85 & 21.48 & 0.00013 \\
$\begin{array}{l}\text { Unidentifiable } \\
\quad-\end{array}$ & 53.7 & 1.29 & 1.44 & 1.51 & 0.557 \\
$\begin{array}{l}\text { Red-winged Blackbird } \\
\text { Agelaius phoenicus }\end{array}$ & 41.3 & 4.56 & 81.54 & 11.84 & 0.00102 \\
$\begin{array}{l}\text { Loggerhead Shrike } \\
\quad \text { Lanius ludovicianus }\end{array}$ & 41.0 & 1.17 & 4.20 & 0.35 & 0.00007 \\
$\begin{array}{l}\text { Palm Warbler } \\
\quad \text { Dendroica palmarum }\end{array}$ & 40.8 & 7.55 & 40.33 & 71.33 & 0.87724 \\
$\begin{array}{l}\text { Purple martin } \\
\quad \text { Progne subis }\end{array}$ & 27.9 & 4.39 & 17.46 & 27.44 & 0.82355 \\
$\begin{array}{l}\text { Spot-breasted Oriole } \\
\text { Icterus pectoralis }\end{array}$ & 20.4 & 0.84 & 1.53 & 0.45 & 0.02077 \\
$\begin{array}{c}\text { Canary-winged Parakeet } \\
\text { Brotogeris versicoloris }\end{array}$ & 19.2 & 0.72 & 3.24 & 0.53 & 0.00174 \\
$\begin{array}{c}\text { Cardinal } \\
\quad \text { Cardinalis cardinalis }\end{array}$ & 17.9 & 0.93 & 4.83 & 0.99 & 0.00467 \\
$\begin{array}{c}\text { Fish Crow } \\
\text { Corvus ossifragus }\end{array}$ & 17.4 & 0.35 & 0.37 & 0.10 & 0.01697 \\
\hline
\end{tabular}

* Probability that the two variances are the same based on the F-ratio.

** Other includes less frequently seen species such as Cattle Egret (Bubulucus ibis), Chimmney Swift (Chaetura pelagica) Killdeer

(Charadrius vociferous), Laughing Gull (Larus atricilla), Ring-billed Gull (Larus delawarensis), Black-headed Gull (Larus ridibundus), White-crowned Pigeon (Columba leucocephala), Parrots (Psittidae), Hill Myna (Gracula religiosa), Downy Woodpecker (Picoides pubescens), Hairy Woodpecker (Picoides villosus), Little Tern (Sterna albifrons), Eastern Kingbird (Tyrannus tyrannus), Gray Kingbird (Tyrannus dominicensis), Great-crested Flycatcher (Myiarchus crinittus), Gray Catbird (Dumatella carolinensis), Brown Thrasher

(Toxostomata rufum), American Robin (Turdus migratorius),Turkey Vulture (Cathartes aura), Sharp-shinned Hawk (Accipiter striatus), Osprey (Pandion haliaetus) Swallow-tailed Kite (Elanoides forficatus) and various raptors (Accipitridae). 
Table 2. Means and variances pooled by month for the 10 most abundant species. Variance to mean ratio indicates extent of seasonal heterogeneity. Coefficient of determination and significance of the regression of monthly means on variances $(n=12)$.

\begin{tabular}{lllllc} 
SPECIES & MEAN & VAR & Var/Mean & $\mathrm{R}^{2}$ & $\mathrm{P}$ \\
\hline Eurasian Collared Dove & 92.75 & 575.28 & 6.20 & 0.46 & 0.0140 \\
European Starling & 79.10 & 722.70 & 9.14 & 0.60 & 0.0030 \\
Boat-tailed Grackle & 67.59 & 314.17 & 4.64 & 0.74 & 0.0003 \\
Mourning Dove & 66.09 & 406.00 & 6.14 & 0.18 & 0.1500 \\
House sparrow & 52.52 & 511.61 & 9.74 & 0.55 & 0.0055 \\
Rock Dove & 39.71 & 148.13 & 3.73 & 0.79 & 0.0001 \\
Northern Mockingbird & 34.55 & 90.31 & 2.61 & 0.44 & 0.0170 \\
Blue Jay & 16.98 & 47.35 & 2.78 & 0.84 & 0.0001 \\
Monk Parakeet & 9.70 & 19.33 & 1.99 & 0.78 & 0.0001 \\
Red-bellied Woodpecker & 6.08 & 3.92 & 0.64 & 0.77 & 0.0002 \\
\hline
\end{tabular}

Table 3. Means and variances pooled by segment for the 10 most abundant species. Variance to mean ratio indicates extent of spatial heterogeneity. Coefficient of determination and significance of the regression of segment means on variances $(n=23)$.

\begin{tabular}{lllllc} 
SPECIES & MEAN & VAR & Var/Mean & $\mathrm{R}^{2}$ & $\mathrm{P}$ \\
Eurasian Collared Dove & 91.14 & 8992.31 & 98.67 & 0.83 & 0.0001 \\
European Starling & 83.67 & 1541.36 & 18.42 & 0.52 & 0.0001 \\
Boat-tailed Grackle & 70.30 & 1283.61 & 18.26 & 0.50 & 0.0001 \\
Mourning Dove & 64.54 & 865.24 & 13.40 & 0.51 & 0.0001 \\
House Sparrow & 47.50 & 1741.71 & 36.66 & 0.67 & 0.0001 \\
Rock Dove & 42.32 & 2105.52 & 49.75 & 0.75 & 0.0001 \\
Northern Mockingbird & 33.98 & 70.88 & 2.09 & 0.16 & 0.0510 \\
Blue Jay & 17.18 & 81.58 & 4.75 & 0.82 & 0.0001 \\
Monk Parakeet & 8.89 & 148.83 & 16.74 & 0.43 & 0.0006 \\
Red-bellied Woodpecker & 6.25 & 14.36 & 2.30 & 0.55 & 0.0001 \\
\hline
\end{tabular}


Table 4. Test statistics for the interaction between time $(\mathrm{df}=3)$ and month $(\mathrm{df}=6)$ in the overdispersed poisson regression analysis of density $(\mathrm{df}=104)$.

\begin{tabular}{llcll}
\hline & \multicolumn{2}{c}{ Model Goodness of Fit } & \multicolumn{2}{c}{ Likelihood Ratio Statistics } \\
Species & $\mathrm{X}^{2}$ & $\mathrm{P}$ & $\mathrm{F}$ & $\mathrm{P}$ \\
\hline Mourning Dove & 97.20 & 0.66 & 2.33 & 0.0100 \\
House Sparrow & 107.78 & 0.38 & 3.64 & 0.0002 \\
Northern Mockingbird & 104.74 & 0.46 & 7.87 & 0.0001 \\
Blue Jay & 98.87 & 0.62 & 3.80 & 0.0001 \\
\hline
\end{tabular}

Table 5. Test statistics for the interaction between time $(\mathrm{df}=3)$ and segment $(\mathrm{df}=23)$ in the overdispersed poisson regression analysis of density $(\mathrm{df}=1239)$.

\begin{tabular}{llcll}
\hline & \multicolumn{2}{c}{ Model Goodness of Fit } & \multicolumn{2}{c}{ Likelihood Ratio Statistics } \\
Species & $\mathrm{X}^{2}$ & $\mathrm{P}$ & $\mathrm{F}$ & $\mathrm{P}$ \\
\hline Mourning Dove & 1121.27 & 0.99 & 2.73 & 0.0001 \\
House Sparrow & 964.91 & 1.00 & 2.26 & 0.0001 \\
Northern Mockingbird & 1049.41 & 1.00 & 3.26 & 0.0001 \\
Blue Jay & 27.96 & 1.00 & 1.44 & 0.0316 \\
\hline
\end{tabular}

Table 6. Test statistics for the month effect in the overdispersed poisson regression analysis of density $(\mathrm{df}=12)$.

\begin{tabular}{llcll}
\hline & \multicolumn{2}{c}{ Model Goodness of Fit } & \multicolumn{2}{c}{ Likelihood Ratio Statistics } \\
Species & $\mathrm{X}^{2}$ & $\mathrm{P}$ & $\mathrm{F}$ & $\mathrm{P}$ \\
\hline Eurasian Collared Dove & 248.78 & 0.40 & 4.92 & 0.0001 \\
European Starling & 230.30 & 0.73 & 4.23 & 0.0001 \\
Boat-tailed Grackle & 248.94 & 0.40 & 4.92 & 0.0001 \\
Mourning Dove & 229.32 & 0.74 & 3.97 & 0.0001 \\
House Sparrow & 216.69 & 0.90 & 4.13 & 0.0001 \\
Rock Dove & 249.09 & 0.40 & 2.36 & 0.0087 \\
Northern Mockingbird & 248.18 & 0.40 & 12.45 & 0.0001 \\
Blue Jay & 250.44 & 0.37 & 11.74 & 0.0001 \\
Monk Parakeet & 145.28 & 0.99 & 1.53 & 0.1133 \\
Red-bellied Woodpecker & 247.34 & 0.43 & 1.64 & 0.0867 \\
\hline
\end{tabular}


Table 7. Test statistics for segment effects in the overdispersed poisson regression analysis of density $(\mathrm{df}=231)$.

\begin{tabular}{lllll}
\hline & \multicolumn{2}{c}{ Model Goodness of Fit } & \multicolumn{2}{c}{ Likelihood Ratio Statistics } \\
Species & $\mathrm{X}^{2}$ & $\mathrm{P}$ & $\mathrm{F}$ & $\mathrm{P}$ \\
\hline Eurasian Collared Dove & 242.93 & 0.28 & 73.18 & 0.0001 \\
European Starling & 220.11 & 0.70 & 5.16 & 0.0001 \\
Boat-tailed Grackle & 238.87 & 0.34 & 10.41 & 0.0001 \\
Mourning Dove & 225.95 & 0.58 & 5.50 & 0.0001 \\
House Sparrow & 226.31 & 0.57 & 19.13 & 0.0001 \\
Rock Dove & 214.92 & 0.77 & 28.61 & 0.0001 \\
Northern Mockingbird & 234.13 & 0.43 & 6.26 & 0.0001 \\
Blue Jay & 248.60 & 0.20 & 9.64 & 0.0001 \\
Monk Parakeet & 160.20 & 0.99 & 6.07 & 0.0001 \\
Red-bellied Woodpecker & 245.02 & 0.25 & 3.84 & 0.0001 \\
\hline
\end{tabular}

Table 8. Test statistics for regional difference in the overdispersed poisson regression analysis of density $(\mathrm{df}=252)$.

\begin{tabular}{lllll}
\hline \multirow{2}{*}{ Species } & \multicolumn{2}{c}{ Model Goodness of Fit } & \multicolumn{2}{c}{ Likelihood Ratio Statistics } \\
\hline Eurasian Collared Dove & 235.79 & $\mathrm{P}$ & $\mathrm{F}$ & $\mathrm{P}$ \\
European Starling & 248.33 & 0.76 & 193.47 & 0.0001 \\
Boat-tailed Grackle & 261.91 & 0.55 & 3.61 & 0.0585 \\
Mourning Dove & 224.04 & 0.32 & 43.08 & 0.0001 \\
House Sparrow & 219.02 & 0.89 & 6.65 & 0.0105 \\
Rock Dove & 206.52 & 0.93 & 4.72 & 0.0307 \\
Northern Mockingbird & 248.84 & 0.98 & 0.03 & 0.8501 \\
Blue Jay & 235.83 & 0.54 & 0.60 & 0.4384 \\
Monk Parakeet & 157.78 & 0.76 & 23.53 & 0.0001 \\
Red-bellied Woodpecker & 243.99 & 0.99 & 0.32 & 0.5746 \\
\hline
\end{tabular}




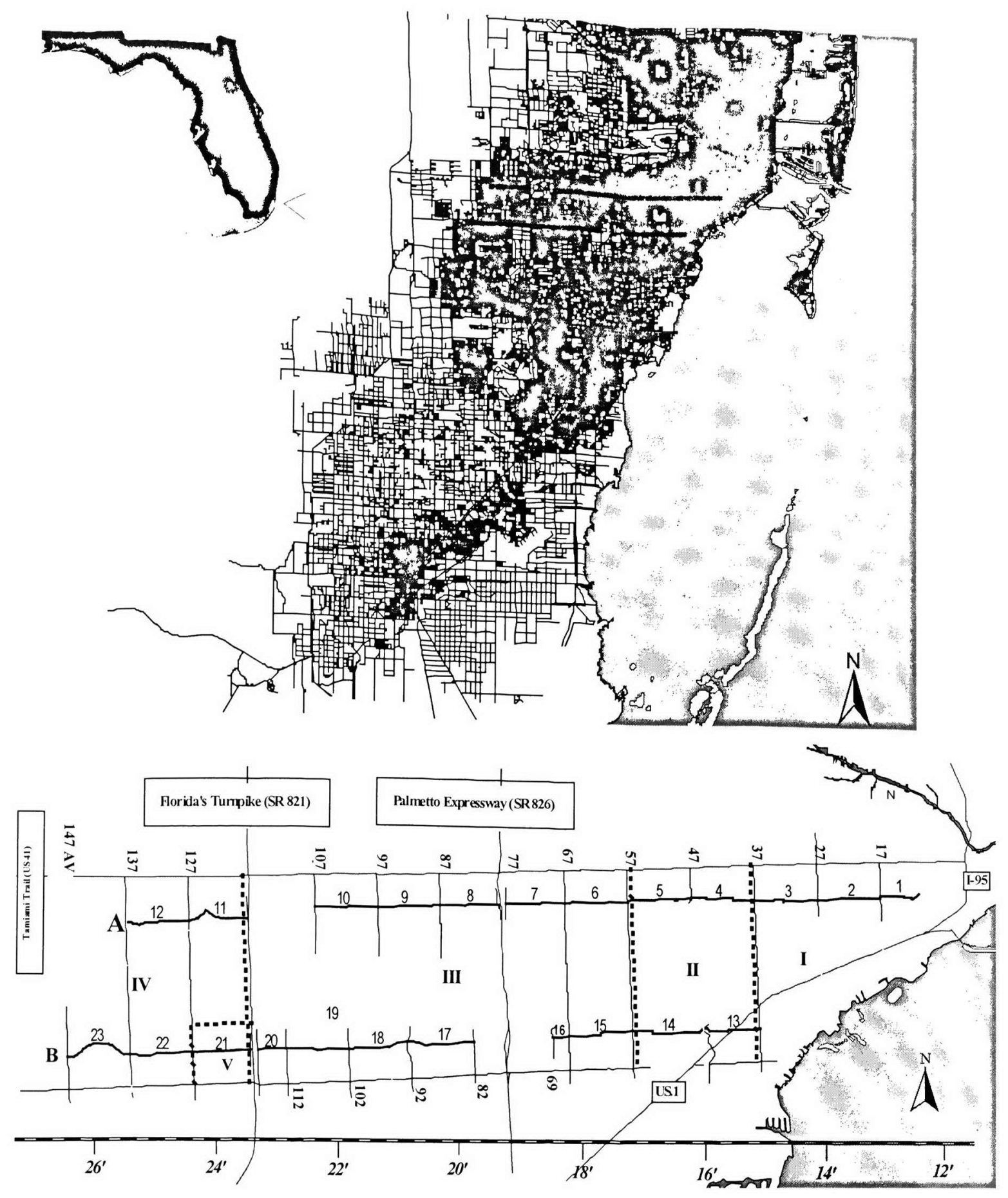

Figure 1. State of Florida (upper left) showing location of Study Area in Metropolitan Miami (upper right). Bold horizontal lines denote transects which are shown in greater detail (bottom) relative to streets, expressways, and longitude shown as $80^{\circ} \mathrm{W}$. Transect 1 follows $16^{\text {th }}$ Street. Transect 2 follows $48^{\text {th }}$ Street; both are divided into segments (numbered 1-23). Dashed lines delineate habitat types labeled with roman numerals 
Collared Dove

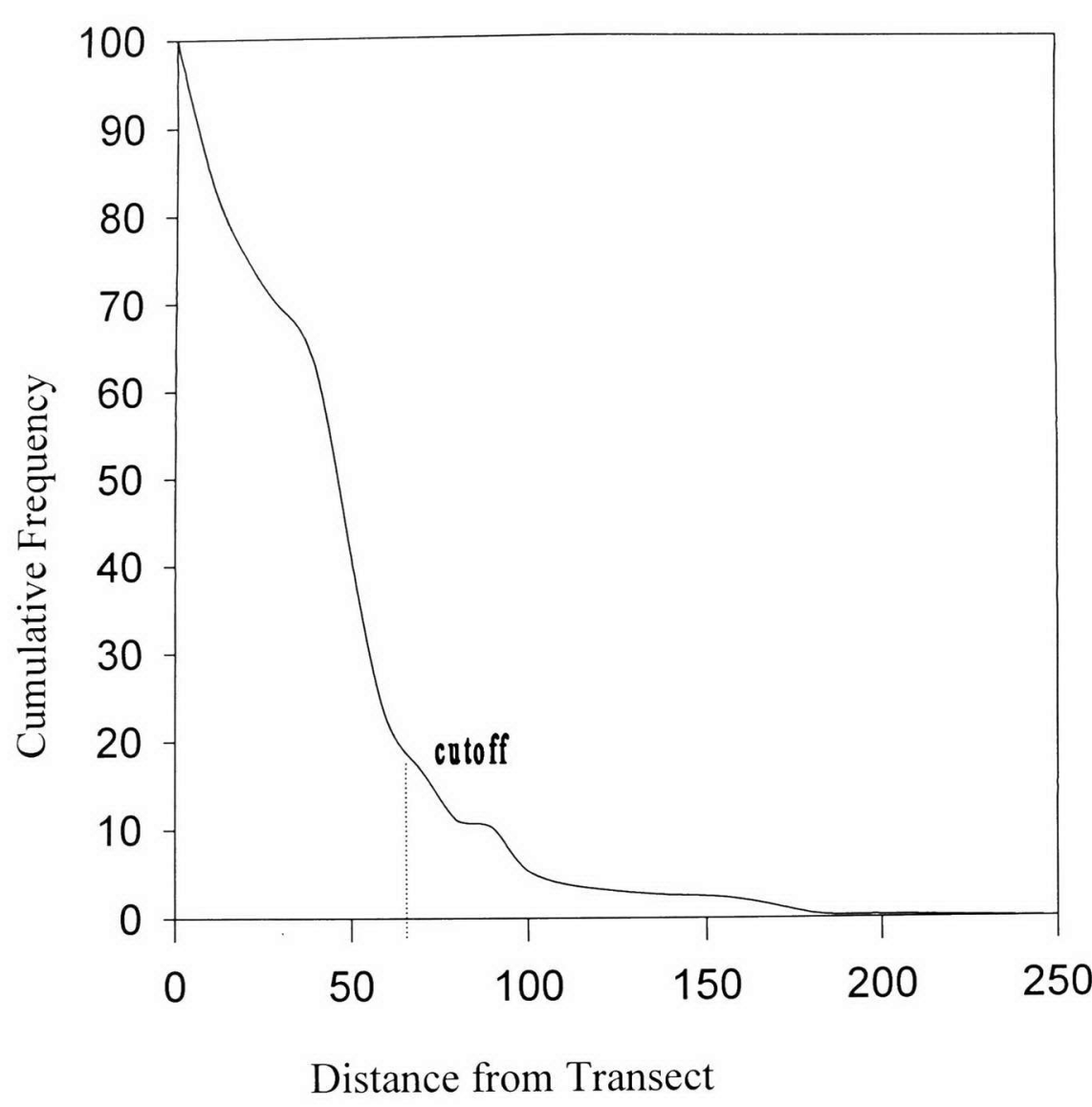

Red-bellied Woodpecker

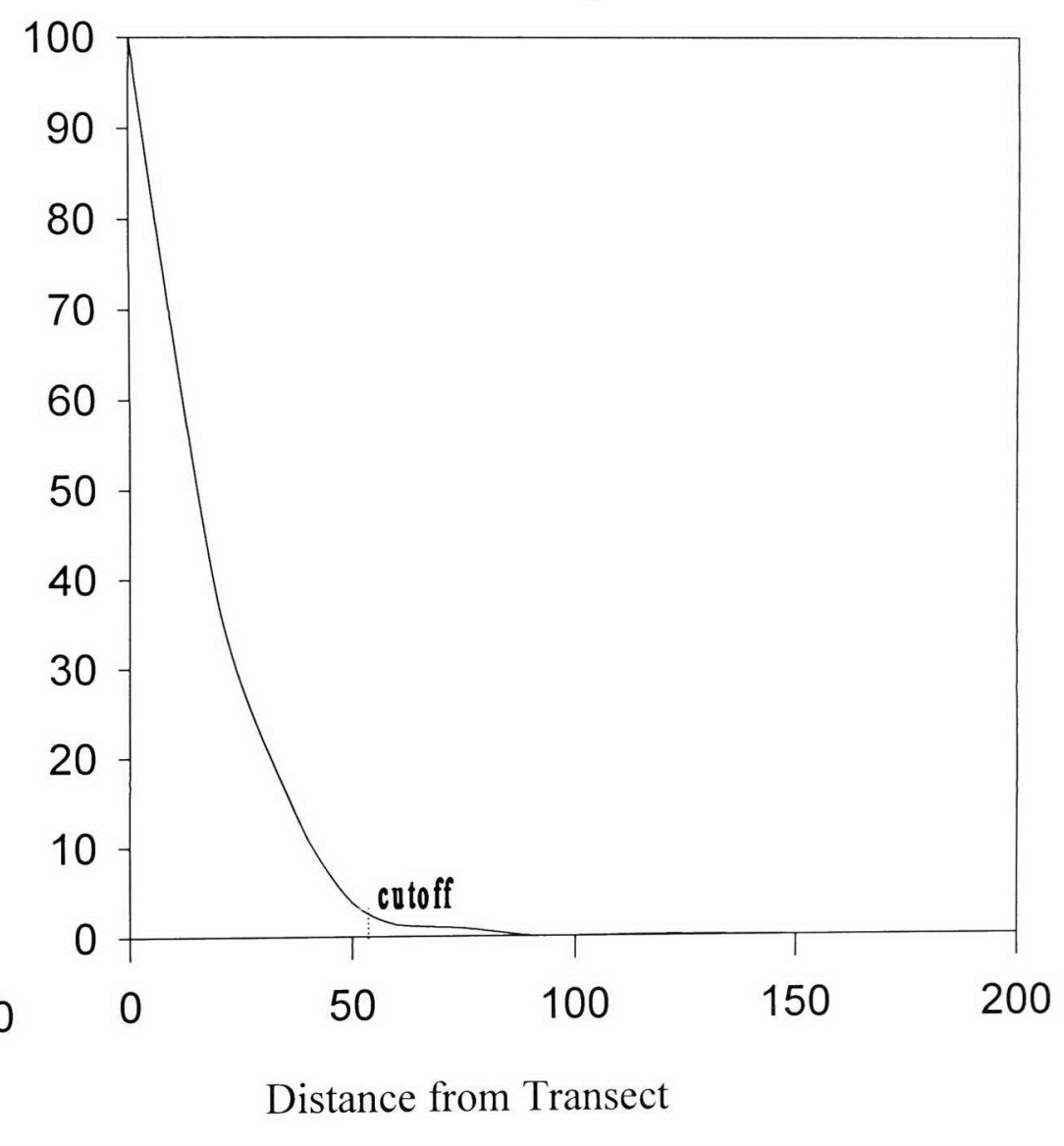

Figure 2. Graphs of cumulative frequency versus distance from which cutoff point was determined 


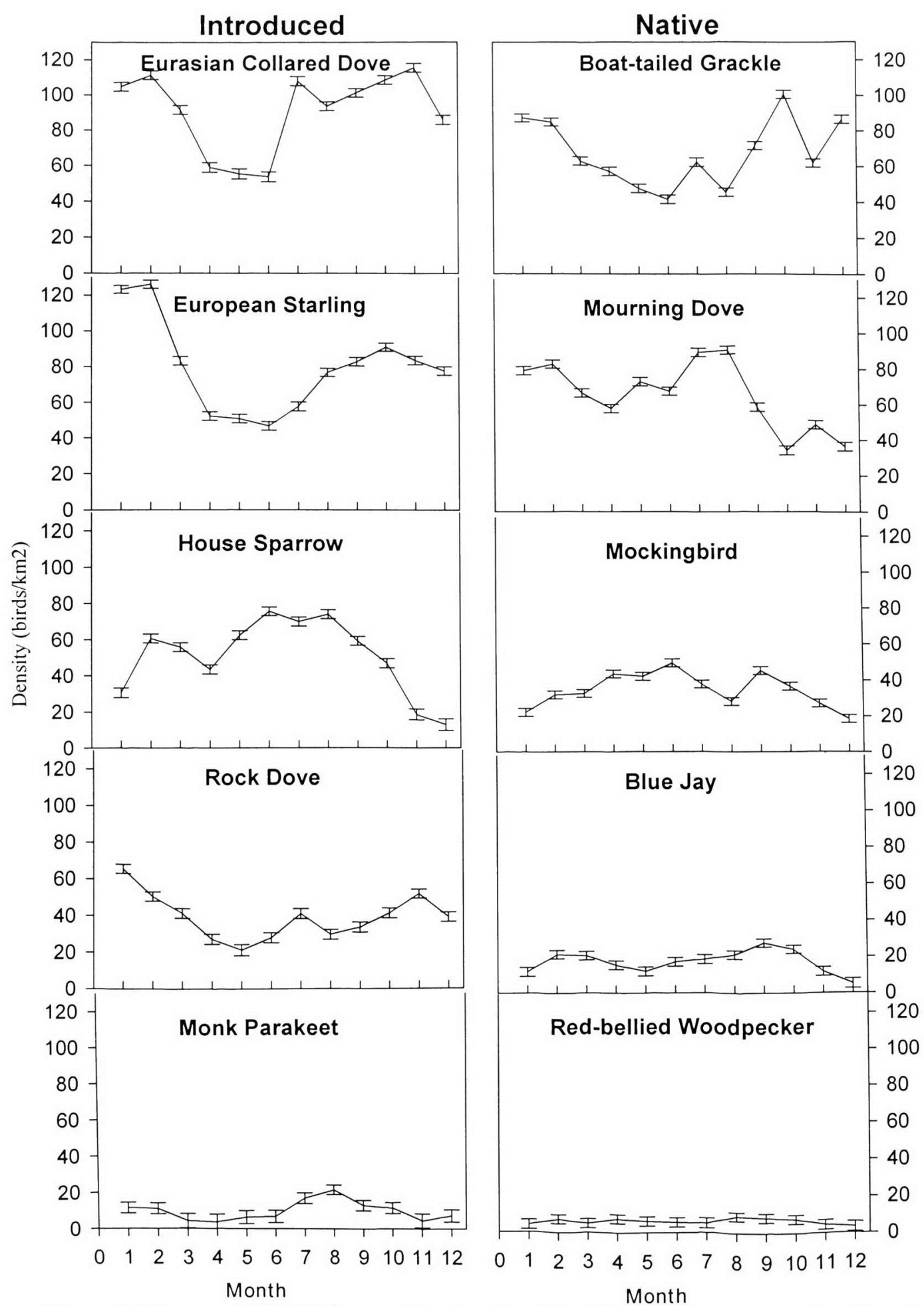

Figure 3. Mean and 95\% CI for monthly density of the 10 most abundant species $($ Jan=1; Dec=12). 


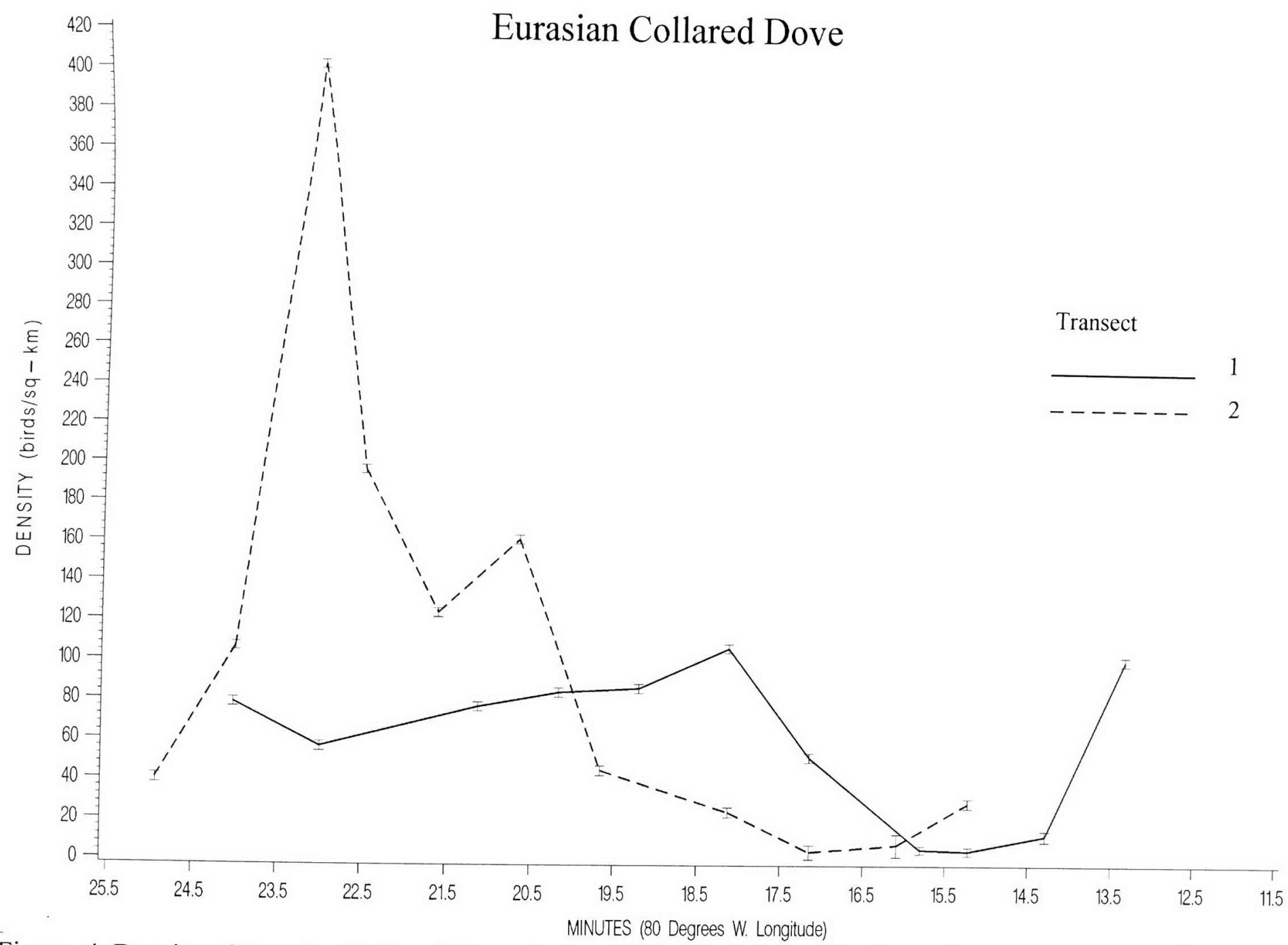

Figure 4. Density of Eurasian Collared Doves by longitude. Each data point shows the segment mean and $95 \%$ CI. Lines connect adjacent points for each transect. 


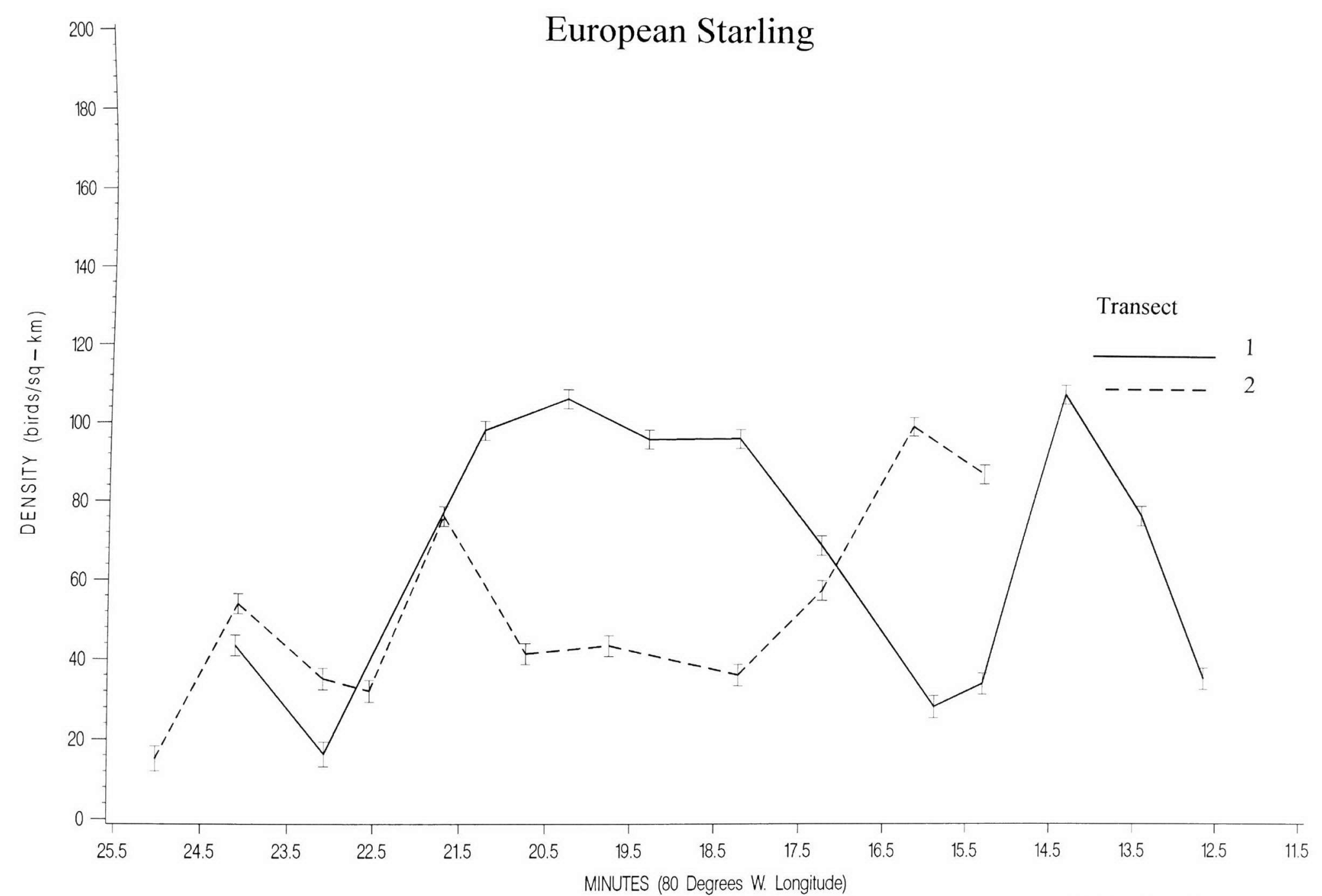

Figure 5. Density of European Starlings by longitude. Each data point shows the segment mean and 95\% CI. Lines connect adjacent points for each transect. 


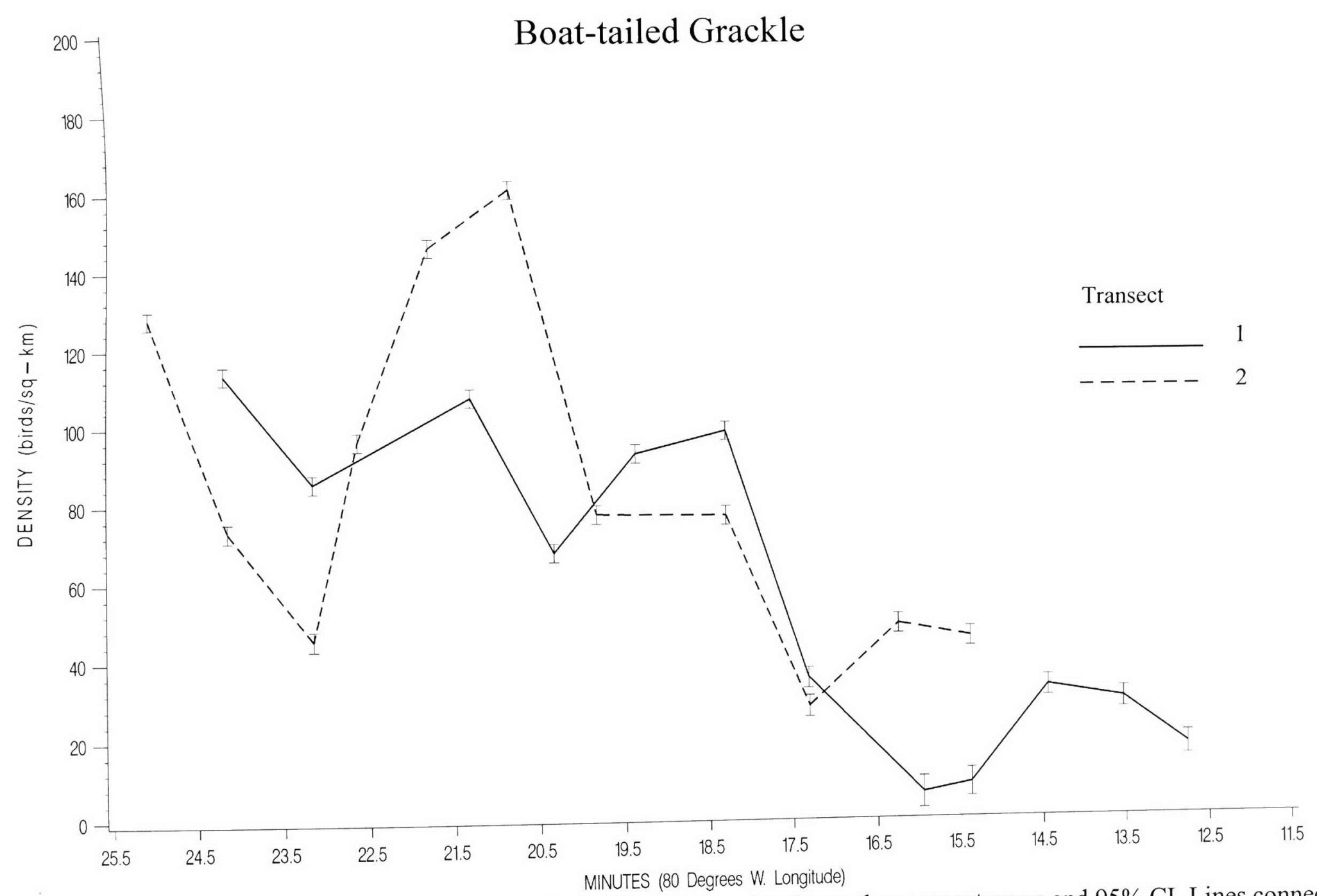

Figure 6. Density of Boat-tailed Grackles by longitude. Each data point shows the segment mean and $95 \%$ CI. Lines connect adjacent points for each transect. 


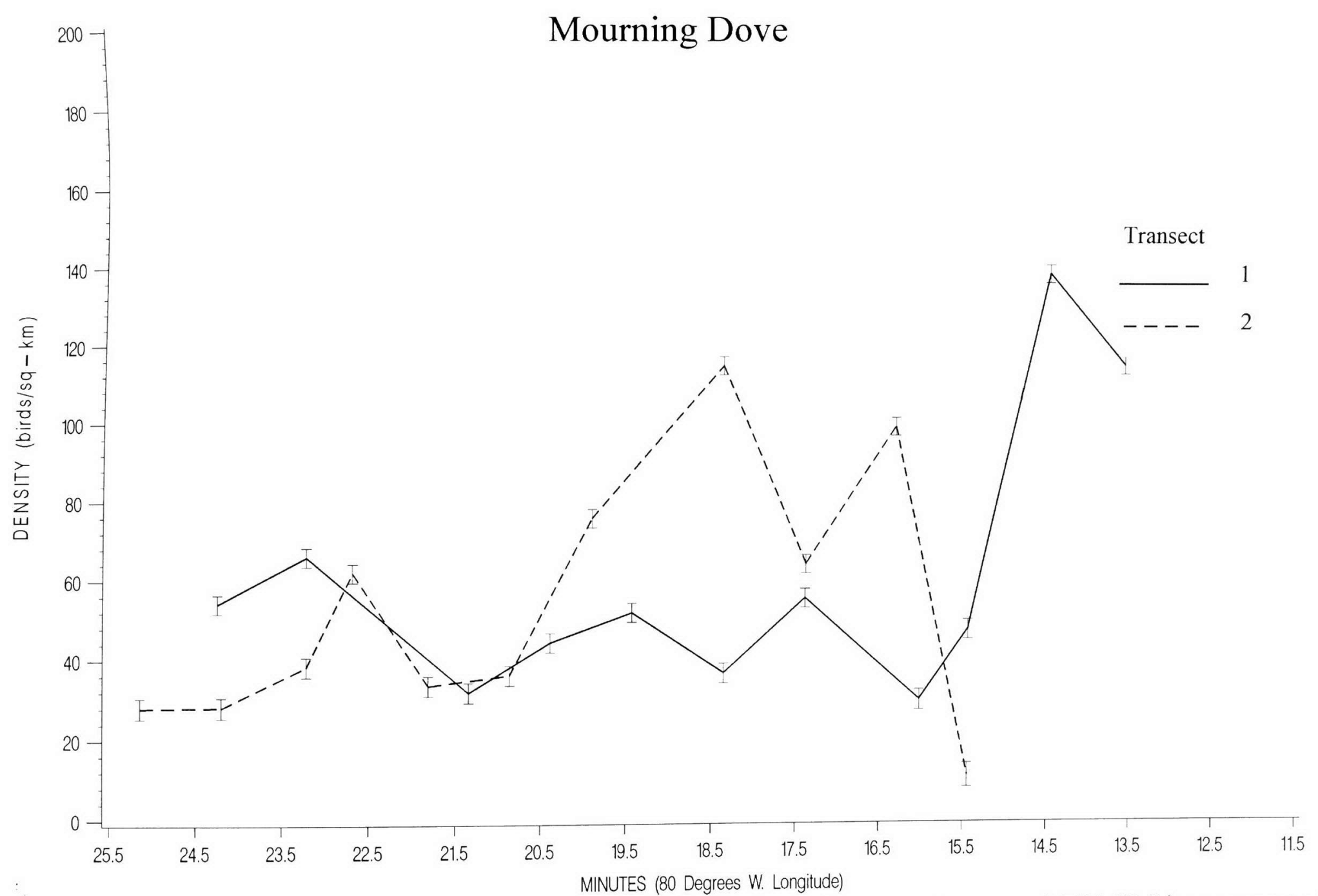

Figure 7. Density of Mourning Doves by longitude. Each data point shows the segment mean and $95 \%$ CI. Lines connect adjacent points for each transect. 


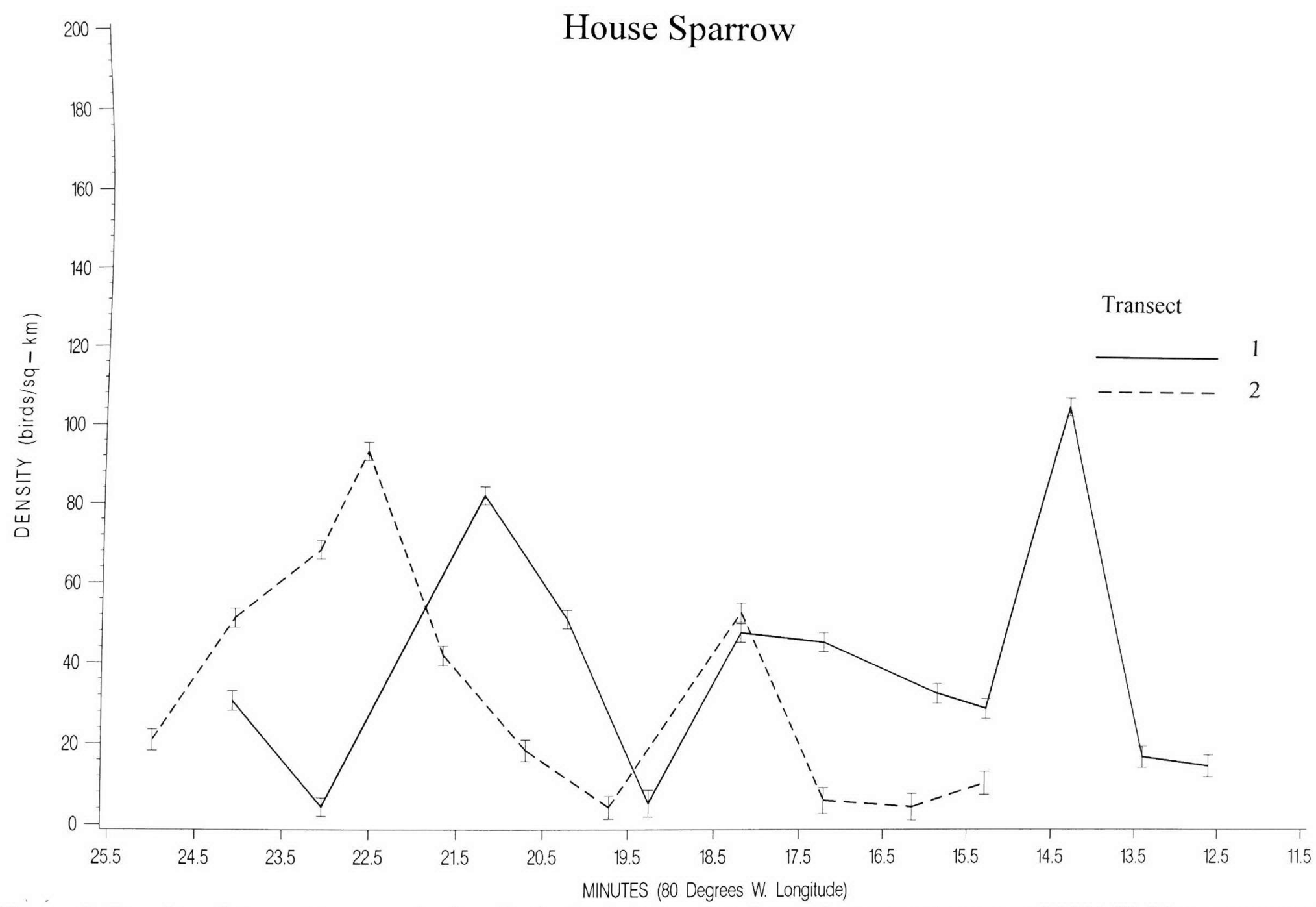

Figure 8. Density of House Sparrows by longitude. Each data point shows the segment mean and $95 \%$ CI. Lines connect adjacent points for each transect. 


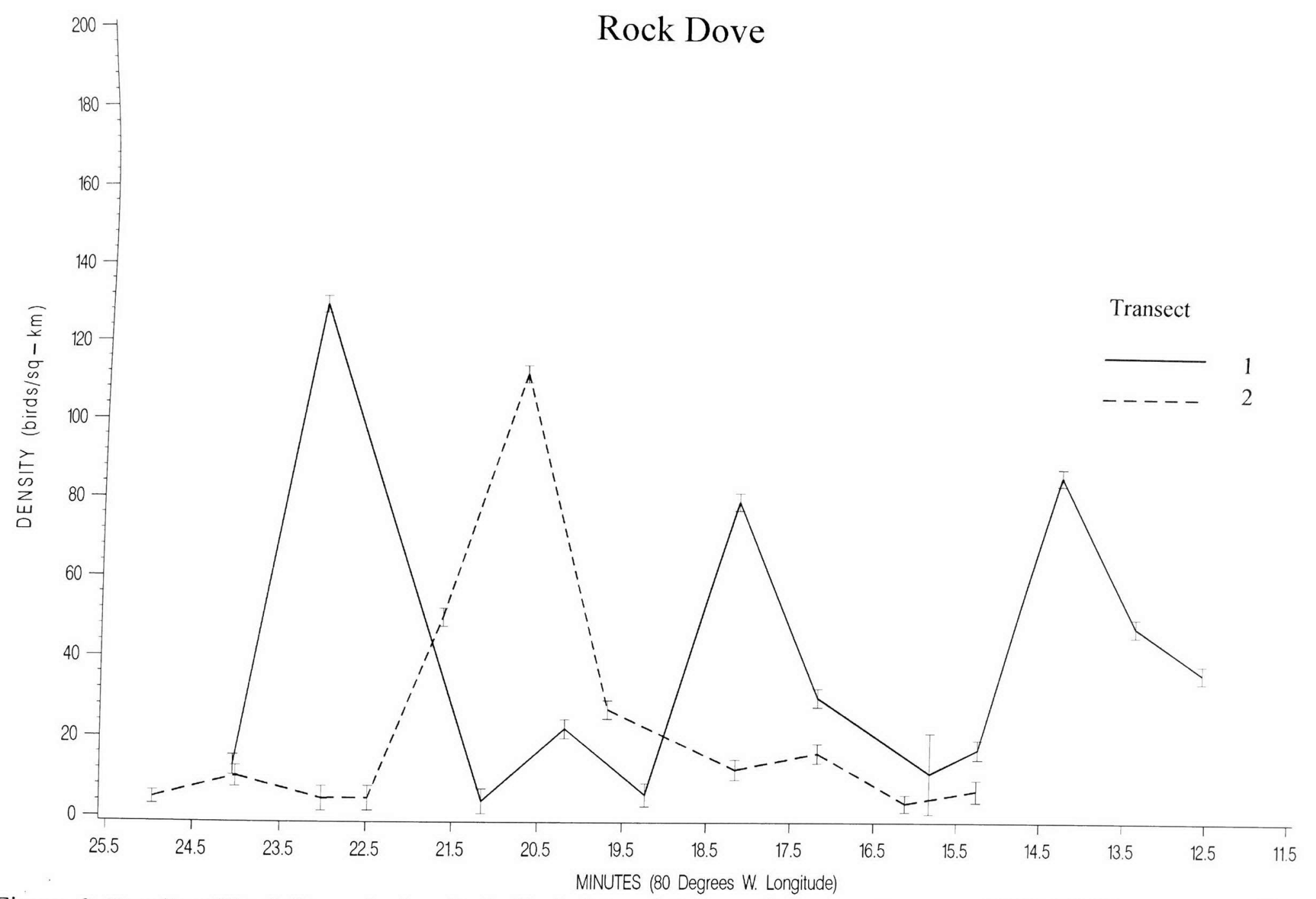

Figure 9. Density of Rock Doves by longitude. Each data point shows the segment mean and $95 \%$ CI. Lines connect adjacent points for each transect. 


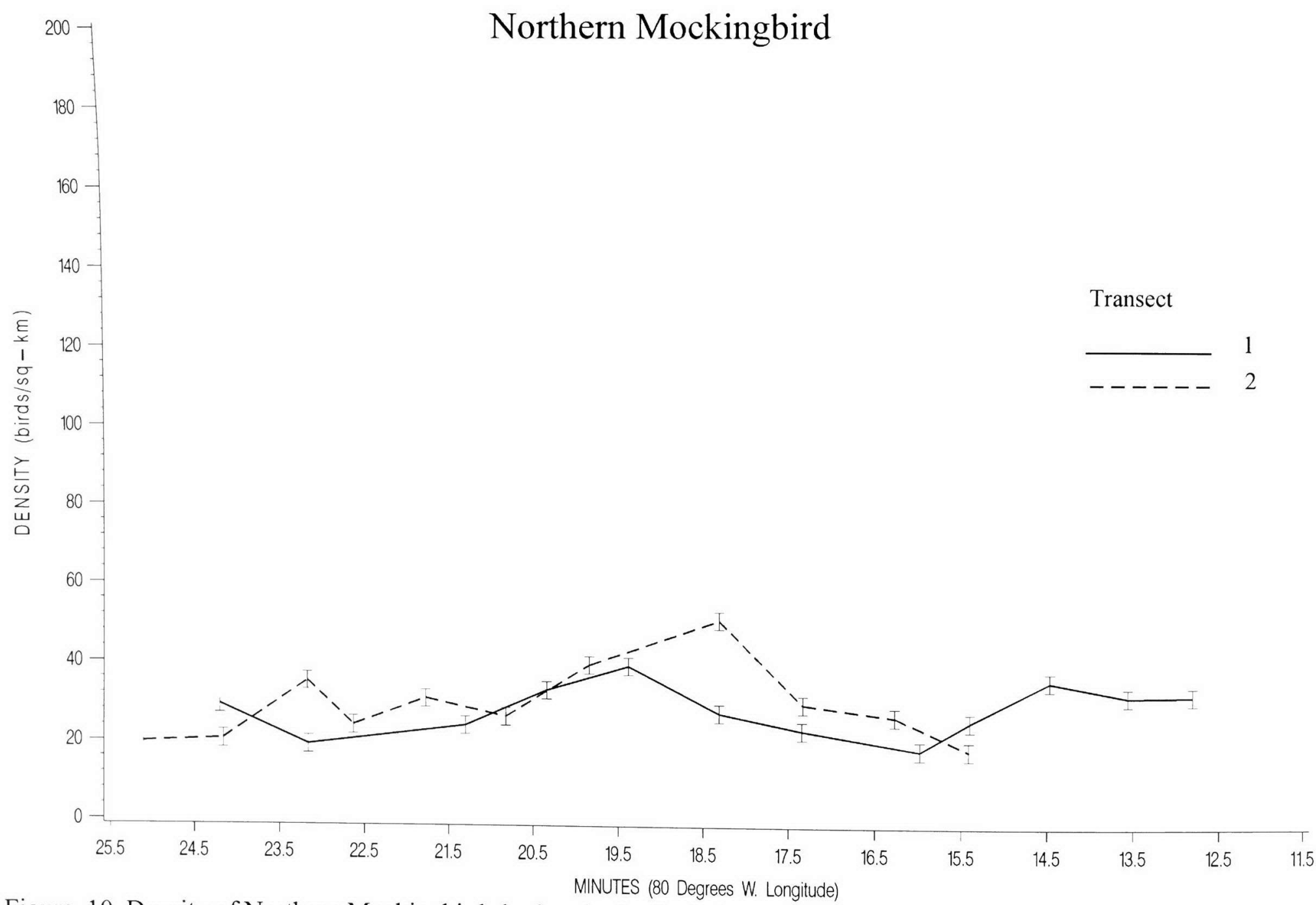

Figure 10. Density of Northern Mockingbirds by longitude. Each data point shows the segment mean and $95 \%$ CI. Lines connect adjacent points for each transect. 


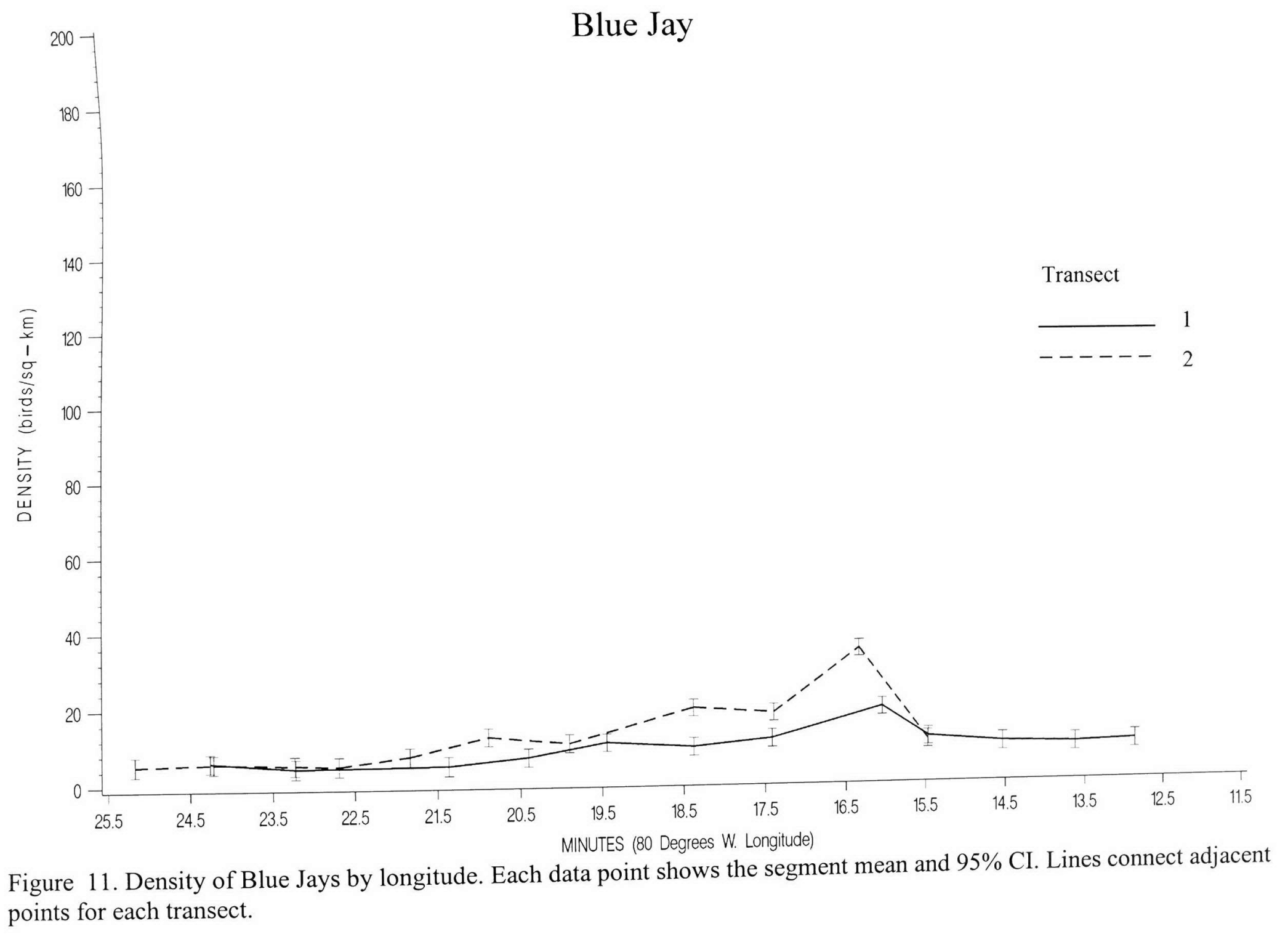




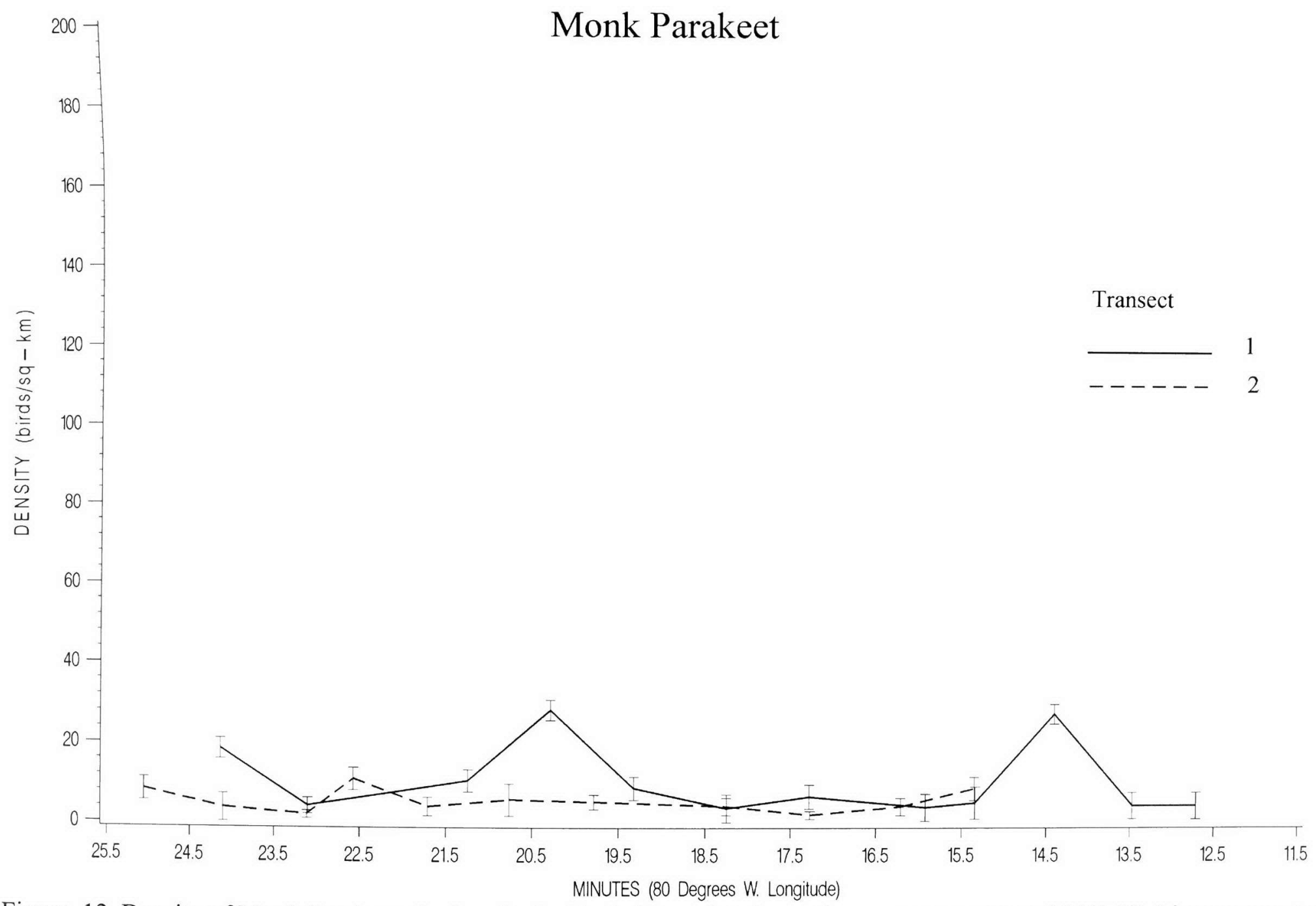

Figure 12. Density of Monk Parakeets by longitude. Each data point shows the segment mean and $95 \%$ CI. Lines connect adjacent points for each transect. 


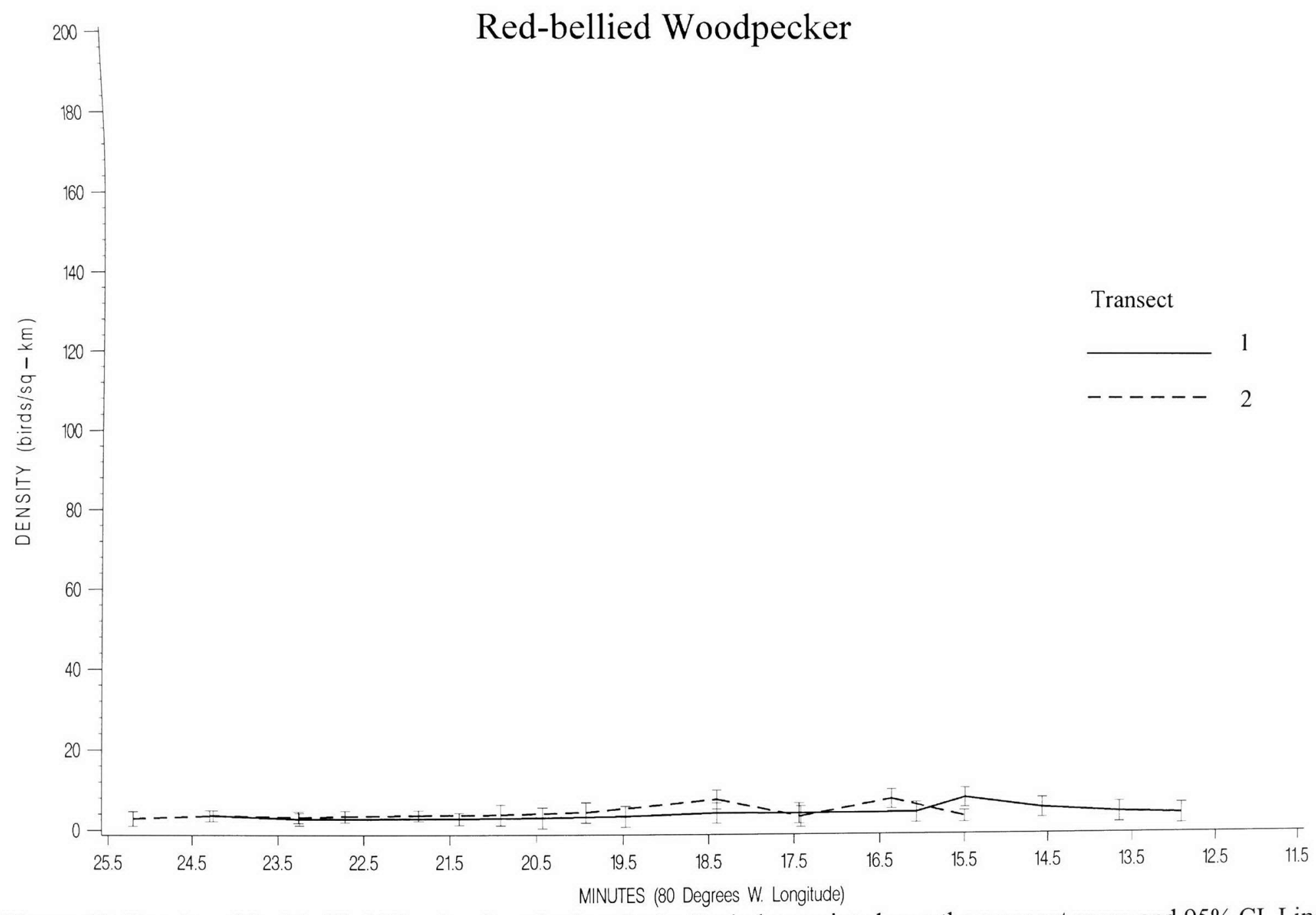

Figure 13. Density of Red-bellied Woodpeckers by longitude. Each data point shows the segment mean and 95\% CI. Lines connect adjacent points for each transect. 


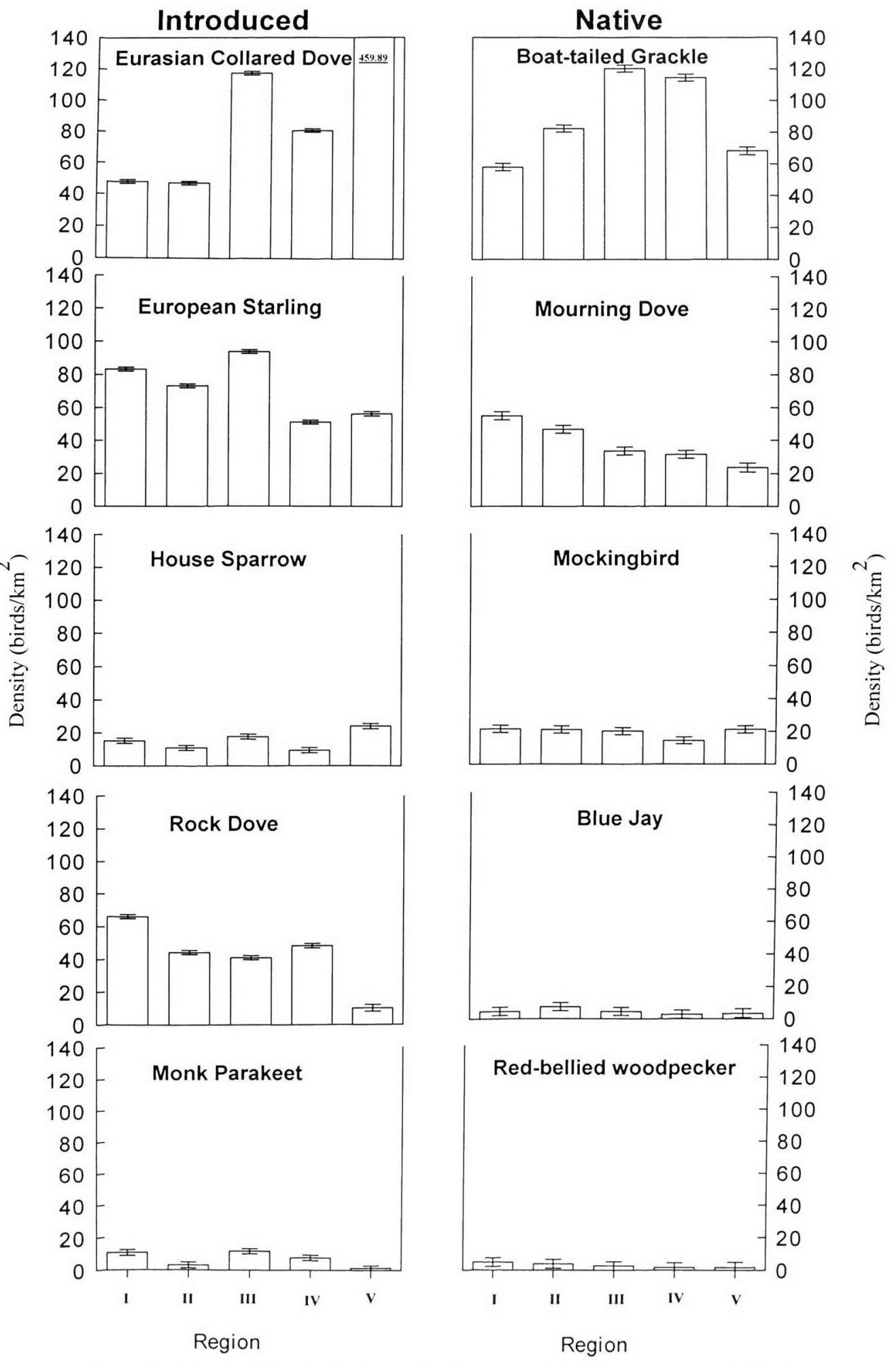

Figure 13. Mean Density in Different Regions of the Study Area (error bars represent 95\% CI) 